\title{
BRACHIOPODS FROM THE RÍO DEL PEÑÓN FORMATION, RÍO BLANCO BASIN, UPPER PALAEOZOIC OF ARGENTINA
}

\author{
Gabriela A. CISTERNA ${ }^{l}$ and Tristán SIMANAUSKAS ${ }^{2}$ \\ 'Facultad de Ciencias Naturales e Instituto Miguel Lillo, Miguel Lillo 205, 4000 San \\ Miguel de Tucumán, Argentina. \\ ${ }_{2}^{2}$ Museo de La Plata, Paseo del Bosque s/n, 1900 La Plata, Argentina
}

\begin{abstract}
Cisterna, G.A. and Simanauskas, T. 2000. Brachiopods from the Río del Peñón Formation, Río Blanco Basin, Upper Palaeozoic of Argentina. [Braquiópodos de la Formación Río del Peñón, Cuenca Río Blanco, Paleozoico Superior de Argentina.] Revista Española de Paleontología, 15(2), 129-151. ISSN 0213-6937.
\end{abstract}

\begin{abstract}
This paper reviews the brachiopod fauna from the Río del Peñón Formation, Río Blanco Basin, Upper Palaeozoic of La Rioja province, Argentina. Traditionally, this unit was referred to the Carboniferous, however the braquiopod fauna here studied suggests a new biostratigraphical interpretation, indicating an age range from the latest Carboniferous to Early Permian. Three different brachiopod assemblages can be identified in the section: Assemblage I, from the lower member, includes Streptorhynchus? sp., Dyschrestia? sp., Costatumulus sp. A, Trigonotreta sp., Spiriferellina sp., Orbiculoidea sp., and unidentifiable productids and strophomenids. Assemblage II, from the middle member, includes Tivertonia jachalensis (Amos), Kochiproductus riojanus (Leanza), Costatumulus sp. B, Trigonotreta riojanensis (Lech and Aceñolaza) and Orbiculoidea sp. Assemblage III, from the highest part of the middle member, includes Neochonetes pegnonensis sp. nov., Costatumulus sp. C, Rhynchopora sp., Septosyringothyris jaguelensis Lech, and Orbiculoidea sp. These brachiopod assemblages demonstrate close affinities with faunas from the lower Permian of Western Australia and India. Affinities with faunas from Perú and Texas are less close.
\end{abstract}

Keywords: Brachiopods, Upper Palaeozoic, Systematic Palaeontology, Biostratigraphy, Argentina.

\section{RESUMEN}

En este trabajo se revisa la fauna de braquiópodos de la Formación Río del Peñón, cuenca Río Blanco, Paleozoico Superior de la provincia de La Rioja, Argentina. Tradicionalmente, esta unidad ha sido referida al Carbonífero. Sin embargo, la fauna de braquiópodos aquí estudiada sugiere una nueva interpretación bioestratigráfica, indicando un rango de edad Carbonífero terminal-Pérmico Temprano. Tres asociaciones diferentes de braquiópodos pueden ser identificadas en esta sección: La Asociación I, en el miembro inferior, contiene Streptorhynchus? sp., Dyschrestia? sp., Costatumulus sp. A, Trigonotreta sp., Spiriferellina sp., Orbiculoidea sp., prodúctidos y estrofoménidos indeterminados. La asociación II, ubicada en el miembro medio, incluye Tivertonia jachalensis (Amos), Kochiproductus riojanus (Leanza), Costatumulus sp. B, Trigonotreta riojanensis (Lech y Aceñolaza) y Orbiculoidea sp. La asociación III, en la parte más alta del miembro medio, contiene Neochonetes pegnonensis sp. nov., Costatumulus sp. C, Rhynchopora sp., Septosyringothyris jaguelensis Lech y Orbiculoidea sp. En términos generales, el conjunto faunístico aquí estudiado exhibe gran afinidad con faunas del Pérmico inferior del Oeste de Australia e India y, en menor grado, con las americanas de Perú y Texas.

Palabras clave: Braquiópodos, Paleozoico Superior, Paleontología Sistemática, Bioestratigrafía, Argentina.

\section{INTRODUCTION}

Exposed in the Precordillera of La Rioja as the Rincón Blanco syncline (Fig. 1), the Upper Palaeozoic Río del Peñón Formation (Borrello, 1955; González and Bossi, 1986), was studied from lithofacial, palaeoenvironmental and palaeoecological points of view by Cisterna (1997) and Simanauskas and Cisterna (2000). This paper is a contribution to the taxonomy of the brachiopod fauna contained in this unit and a new biostratigraphical interpretation, indicating an age range from the latest Carboniferous to Early Permian, is also proposed. 


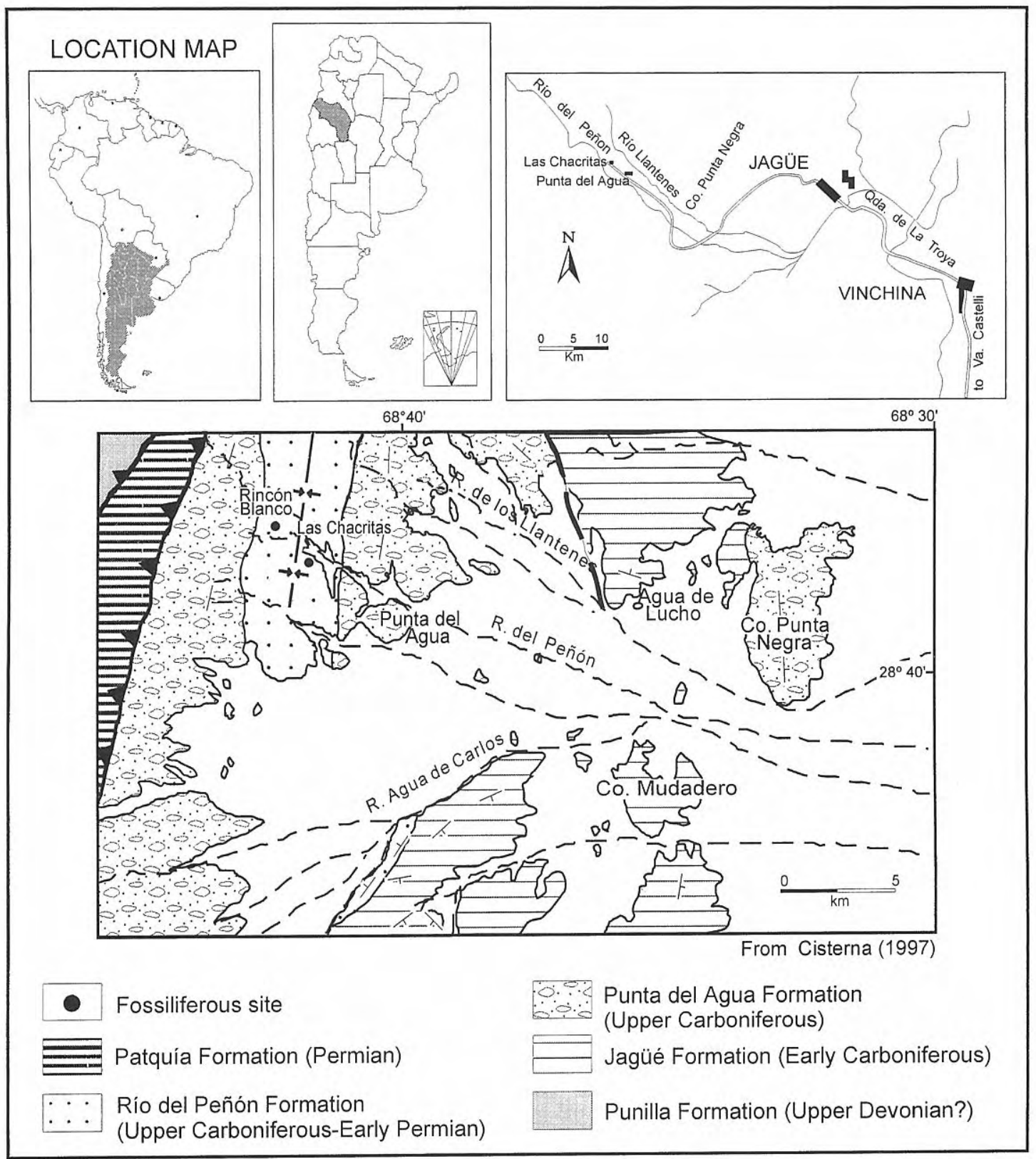

Figure 1. Location map and fossil localities.

Within the faunal assemblages identified in the Río del Peñón section, brachiopods are the most conspicuous element. Earlier studies (Leanza, 1948; Lech and Aceñolaza, 1987) contributed to the knowledge of these faunas. However, new taxa found recently suggest that a revision of the biostratigraphy of the beds containing these brachiopods is now appropriate.

The material studied is housed in the collections of the Miguel Lillo Foundation, Invertebrate Palaeontology Section (PIL).

\section{STRATIGRAPHIC DISTRIBUTION OF THE FAUNA AND BIOSTRATIGRAPHY}

Three different brachiopod assemblages can be identified in the Río del Peñón Formation (Fig. 2):
Assemblage I from the lower member, is composed of fragmentary material and the identifications are at the generic level only. Assemblage II occurs in the middle member, and Assemblage III occurs c. $120 \mathrm{~m}$ above Assemblage II, at the highest part of the middle member.

Assemblage I is situated immediately above of levels with NBG flora (Nothorhacopteris-BotrychiopsisGinkgophyllum) and contains Streptorhynchus? sp., Dyschrestia? sp., Costatumulus sp. A, Trigonotreta sp., Spiriferellina sp., Orbiculoidea sp., and unidentifiable productids and strophomenids. Assemblage I requires further collections in order to determine the precise age of the fauna. However, Trigonotreta and Costatumulus are known only from Permian rocks. Trigonotreta sp. here studied is close to Trigonotreta hesdoensis (Sanhi and Dutt) from the Asselian-Tastubian faunas of peninsular India (Archbold et al., 1996). Costatumulus 


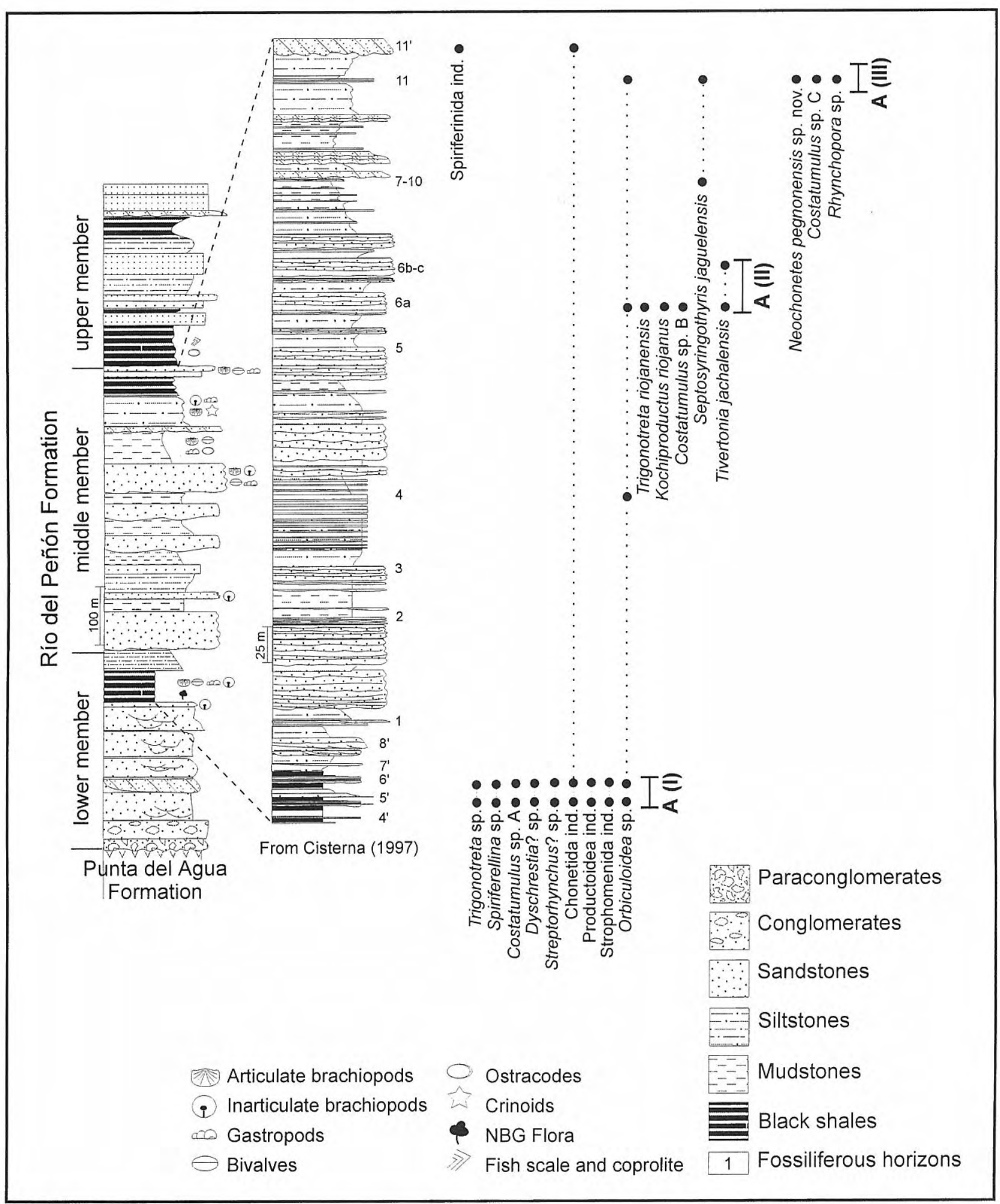

Figure 2. Vertical distribution of the brachiopod assemblages in the faunistic interval of the Río del Peñón Formation.

sp. A resembles Costatumulus parva (Cooper and Grant, 1975) from the early Permian of Texas (Neal Ranch and Skinner Ranch formations). Hence, the presence of this assemblage probably indicates an early Permian age for this horizons of the Río del Peñón Formation.

Species identified in Assemblage II are Tivertonia jachalensis (Amos), Kochiproductus riojanus (Leanza), Costatumulus sp. B, Trigonotreta riojanensis (Lech and
Aceñolaza) and Orbiculoidea sp. This assemblage contains fossils characteristic of the Tivertonia jachalensis-Streptorhynchus inaequiornatus Zone and the section of the Río del Peñon is considered the parastratotype of this biozone (Sabattini et al., 1990).

Costatumulus and Trigonotreta constitute new elements for Tivertonia jachalensis-Streptorhynchus inaequiornatus Zone. Also, among the species identified 
in the Assemblage II, Kochiproductus riojanus and Trigonotreta riojanensis are important fossils for intraand inter-basinal correlation. Kochiproductus riojanus has been recorded from the Quebrada Larga Formation (Antelo, 1972) within the Río Blanco Basin. Trigonotreta riojanensis is closes to Trigonotreta pericoensis (Leanza) described from the Tupe Formation at the Quebrada de la Herradura, Paganzo Basin (Leanza, 1945). Also, the material described as Punctothyris sanjuanensis from the Del Salto Formation, Calingasta-Uspallata Basin (Lech and Aceñolaza, 1990) is very close to our Trigonotreta riojanensis. The genus Tivertonia Archbold includes smooth chonetids from the early Permian of Australia, Himalayas and Argentina. Tivertonia jachalensis is similar to Tivertonia yarrolensis (Maxwell) and Tivertonia chumukensis Archbold and Gaetani, 1993, from the early Permian of eastern Australia and northwestern Himalayas, respectively.

The Tivertonia jachalensis-Streptorhynchus inaequiornatus Zone, originally called Lissochonetes jachalensis-Streptorhynchus inaequiornatus Zone, was referred to the late Carboniferous (Sabattini et al., 1990). However, recent studies of its invertebrate fauna (Cisterna, 1997; Cisterna and Sabattini, 1998), as well as the new age obtained by the K-Ar method from the Punta del Agua Formation (Fauque et al., 1999), underlying to the Río del Peñón Formation, and the stratigraphical distribution of all other species of the genus Tivertonia, suggest an early Permian age.

At the highest part of the middle member appears Assemblage III, which contains Neochonetes pegnonensis sp. nov., Costatumulus sp. C, Rhynchopora sp., Septosyringothyris jaguelensis Lech, and Orbiculoidea sp.

Neochonetes pegnonensis sp. nov. is close to species of the Neochonetes (Sommeriella) pratti lineage, in particular the small species from the early Permian of Western Australia.

Rhynchopora sp. allows comparisons with Permian species such as Rhynchopora australasica Archbold described from the Asselian horizons of the Lyons Group in the Carnarvon Basin, Western Australia (Archbold, 1995). Also, the presence of Rhynchopora sp. in this assemblage is important because it is the first description of the genus from Argentina.

Septosyringothyris is an ubiquitous element in the Carboniferous-Permian of Argentina. Septosyringothyris jaguelensis Lech is described from the Permian Agua del Jagüel Formation of the Precordillera, Mendoza province. Here it is associated with Costatumulus amosi Taboada, Streptorhynchus inaequiornatus Leanza, Crurithyris sp., Orbiculoidea aff. saltensis, Orbiculoidea sp., among others (Lech, 1990). In the section studied by us, Septosyringothyris jaguelensis is not restricted exclusively to Assemblage III, and appears also in lower beds with a diverse fauna of bivalves and gastropods (Fig. 2).

Generally speaking, the brachiopod fauna studied here is a characteristic early Permian fauna of Gondwana. It particularly shows similarities with the Asselian-
Tastubian faunas of Western Australia and with the Asselian-Sakmarian faunas of Tasmania and Eastern Australia. This group of genera appears repeatedly in fossil assemblages of this age in those regions, i.e. Trigonotreta, Costatumulus, Tivertonia, and Neochonetes accompanied by Spiriferellina, Streptorhynchus and Rhynchopora (Archbold, 1995; Archbold et al., 1996).

Thus, the age of the three brachiopod assemblages studied would range between the earliest Asselian and the early Sakmarian (Tastubian). As to the age of the lower member of the Río del Peñón Formation, it is important to point out that Assemblage I is immediately above the beds carrying the NBG Phytozone (Archangelsky and Azcuy, 1985). This phytozone is represented by endemic fossils that prevent a precise chronological correlation and the age is believed to be late Westphalian-Stephanian because of its stratigraphic relation to the overlying Tivertonia jachalensis-Streptorhynchus inaequiornatus Zone (Archangelsky et al., 1996). However, in beds equivalent to the Río del Peñon Formation that are exposed in the Agua de Carlos locality (to the south of the Rincón Blanco locality), the NBG flora appears in association with elements of the Interval phytozone (Archangelsky and Cúneo, 1991), including Krauselcladus argentinus Archangelsky. These elements suggest a younger age still, perhaps latest Carboniferous (Carrizo and Azcuy, 1995; Carrizo, 1998). Thus, the age of the firsts beds of the Río del Peñón Formation, placed immediately below Assemblage I (Fig. 2), may be latest Carboniferous.

Assemblage II shows elements characteristic of the Tivertonia jachalensis-Streptorhynchus inaequiornatus Zone. Inclusion of elements belonging to Assemblages I and II in this biozone would require the study in depth of the fauna at other equivalent sections (Quebrada Larga and Quebrada de la Herradura formations). Assemblage III represents a new faunal assemblage that is obviously younger that the Tivertonia jachalensis-Streptorhynchus inaequiornatus Zone. Therefore, future studies may allow the establishment of a new biostratigraphical unit for the Upper Palaeozoic of the Precordillera.

\section{SYSTEMATIC PALAEONTOLOGY}

\author{
Phylum BRACHIOPODA \\ Order STROPHOMENIDA Öpik, 1934 \\ Suborder ORTHOTETIDINA Waagen, 1884 \\ Superfamily ORTHOTETOIDEA Waagen, 1884 \\ Family Streptorhynchidae Stehli, 1954 \\ Genus Streptorhynchus King, 1850
}

Type species: Terebratulites pelargonatus Schlotheim, 1816.

Streptorhynchus? sp.

Fig. 3 a-g

Locality: Eastern limb of the Rincón Blanco syncline, left bank of the Río del Peñón, 35 km west of Jagüé, La Rioja province. 
Stratigraphic horizon: Río del Peñón Formation, lower member, horizons $5^{\prime}$ and 6'.

Material: Ten incomplete internal moulds of dorsal valves, four of them with their matching externals (IPI 3126a-b, 3127a-b, 3128a-b, 3129, 3130a-b, 3131, 3135, 3136, 3137 and $3138 \mathrm{~A}$ ); one external mould of a dorsal valve (IPI 3133); one external mould of a ventral valve (IPI 3134); one internal mould of an articulate specimen (IPI 3138B); one internal mould of a ventral valve with its matching external (IPI 3132a-b). All material from horizon 6'.

\section{Description}

Shell of small size for the genus (maximum width 15 $\mathrm{mm}$ ); outline transversely subquadrate with maximum width anterior to the hinge line. Ventral valve flat with low and slightly concave interarea. Dorsal valve moderately convex with larger convexity at about mid-length. Surface finely costellate with costellae that increase usually by bifurcation; generally 10 costellae per $5 \mathrm{~mm}$ in the ventral valve and 12 to 13 per $5 \mathrm{~mm}$ in the dorsal valve, both measured at about mid-length of the valves. Shell pseudopunctate, typically of the Streptorhynchus type, preserved on internal moulds as small tubercules arranged in regular radial rows. Dorsal interior with a pair of short and divergent socket plates, joined to a moderately long and bilobate cardinal process. Muscle area sub circular, divided by a very weak median ridge in some specimens. Other characters unknown.

\section{Discussion}

The specimens described possess the characteristic dorsal cardinalia of Streptorhynchus. However, Streptorhynchus species are generally more deeply conical with a proportionately narrower hinge and costellae that increase by intercalation more typically than by bifurcation. Because these features have not been observed in our material, the generic position of this species is questionable.

Streptorhynchus? sp. is characterised fundamentally by its small size for the genus and its fine costellae. This species appears to be close to the finely costellated, thinshelled group of Western Australian Streptorhynchus described by Thomas (1958), particularly with Streptorhynchus johnstonei Thomas (1958, p. 55, pl. 14, figs. 1-6). Both species are similar in terms of general shell morphology and number of costellae but Streptorhynchus? sp. is notably smaller.

In relation with the larger Argentinean species Streptorhynchus inaequiornatus Leanza (1945, p. 286, pl. 3 , figs. $1-7$, pl. 4, figs. 1-9; pl. 5, fig .6), described from the Paganzo Basin (Tupe Formation, Quebrada de la Herradura locality), Streptorhynchus? sp. possess the same number of fine costellae per mm. However, in Streptorhynchus inaequiornatus the costellae show a typical pattern formed by two orders of size.

Order PRODUCTIDA Waagen, 1883

Suborder CHONETIDINA Muir-Wood, 1955

Superfamily CHONETOIDEA Bronn, 1862

Family Rugosochonetidae Muir-Wood, 1962
Subfamily Rugosochonetinae Muir-Wood, 1962 Genus Neochonetes Muir-Wood, 1962

Type species: Chonetes dominus King, 1938.

\section{Remarks}

Archbold (1981) proposed the existence of three lineages within Neochonetes. The first lineage, of $N$. (Neochonetes) carboniferus, comprises upper Carboniferous to lower Permian (Asselian) species from Russia, Spain and China. The second lineage, of $N$. $(N$.) granulifer includes species from the upper Carboniferous to the lower Permian (Sakmarian) of Great Brittain, Germany, North America, Bolivia, and Perú. The third lineage, of Neochonetes (Sommeriella) pratti, grouped species from the Permian of the Himalayas, Arabia, Afghanistan, Iran, the Urals, Alaska, and Western Australia.

Neochonetes pegnonensis sp. nov. is close to the species of the Neochonetes (Sommeriella) pratti lineage, particularly with the species that are small in size and lack a sulcus. The species of the $N$. (Neochonetes) granulifer lineage are different from Neochonetes pegnonensis sp. nov. in showing the maximum width at the hinge. $N$. pegnonensis sp. nov. possibly belongs to the $N$. (Sommeriella) pratti lineage, or more probably to a new, related lineage of the genus Neochonetes.

\section{Neochonetes pegnonensis sp. nov.}

Fig. 3 h-o

Holotype: An internal mould of a ventral valve, IPI 2959 (Fig. 3h).

Type Locality: Western limb of the Rincón Blanco syncline, $35 \mathrm{~km}$ west of Jagüé, La Rioja province.

Type horizon: Río del Peñón Formation, middle member, horizon 11.

Material: One external mould of ventral valve (IPI 2981); ten internal moulds of ventral valves (IPI 2957, 2959, 2960, 2961, 2962, 2967, 2971, 2974, 2976, 2977); three ventral valves (IPI 2958, 2966, 2968); four external moulds of dorsal valves (IPI 2963, 2964, 2972, 2978); two internal moulds of dorsal valves (IPI 2965, 2979); three dorsal interiors (IPI 2969, 2970, 2975). One hundred incomplete moulds and valve fragments (IPI 2973 and 2980).

Derivatio nominis: From the Río del Peñón Formation, Upper Palaeozoic of La Rioja province, Argentina.

\section{Diagnosis}

Shells small, concave-convex, wider than long, subquadrate to subrectagular; hinge line width equal to or slightly shorter than the maximum width, measured at mid-length of shell. External surface covered by very fine radial ribs (capillae), four to five per $\mathrm{mm}$ near the anterior commissure. Interior of ventral valve showing a very short 


\begin{tabular}{|c|c|c|c|c|c|}
\hline IPI N $^{\circ}$ & W & L & VTL & MS & DS \\
\hline 2957 & 10.5 & 9 & 6.5 & 1 & - \\
\hline 2958 & 12.7 & 10 & - & - & - \\
\hline 2959 & 13 & 9.5 & 6.9 & - & - \\
\hline 2960 & 12 & 8.7 & 6.5 & - & 3.1 \\
\hline 2961 & 11 & 9 & 7 & 1 & - \\
\hline 2966 & 8.1 & 6.3 & - & - & - \\
\hline 2967 & 10.8 & 9 & 6.7 & - & 3.4 \\
\hline
\end{tabular}

Ventral valve

\begin{tabular}{|c|c|c|c|}
\hline IPI N $^{\circ}$ & W & L & MS \\
\hline 2963 & 12 & 8.5 & - \\
\hline 2964 & 12.6 & 7.8 & - \\
\hline 2965 & 13.4 & 10.3 & 4.7 \\
\hline 2970 & 11 & 8.2 & 5 \\
\hline 2972 & 11.6 & 7.4 & - \\
\hline 2978 & 10.5 & 7 & - \\
\hline 2979 & 11.8 & 8 & 5 \\
\hline
\end{tabular}

Dorsal valve

Table 1 Measurements in mm of Neochonetes pegnonensis sp. nov. IPI: "Instituto de Paleontología, Sección invertebrados, Fundación Miguel Lillo"; W: maximum width; L: length; VTL: vascular trunk length; MS: median septum; DS: diductor scars.

but high median septum, anteriorly two vascular trunks form prominent ridges with large endospines (papillae) on them. The interior of the dorsal valve shows an anteriorly elevated median septum and well developed brachial ridges with large endospines on them.

\section{Description}

Exterior: Shell small (for measurements see Table 1), concavo-convex, transversally subrectangular in outline. Maximum length slightly larger than two thirds of the maximum width. The width of the hinge line is equal to or slightly shorter than the maximum width, measured at midlength of shell. Cardinal extremities straight or slightly tapering. Sulcus weak to absent. Both valves ornamented with fairly obvious growth lines and very fine ribs (capillae). These ribs number 4 , and more commonly 5 per mm near the anterior commissure. Along the posterior edge of ventral interarea there are at least three spine bases on each side of the umbo; they form an angle of more than $40^{\circ}$ with the hinge.

Interior: Ventral interior shows a high and short median septum, extending approximately one seventh of the valve length. Anteriorly two vascular trunks form prominent ridges with large endospines (papillae) on them. At both sides of the septum are long adductor muscle scars, surrounded by large, round diductor muscle scars, which reach almost mid-length of the valve. Dorsal valve interior carries a tetralobate cardinal process, with a deep pit at its base. Socket ridges thick and long, forming a low angle with the hinge line. In front of the pit there is a very long median septum, about three quarters of the valve length; the anterior end of the septum is formed by a group of large endospines. The anderidia are also long (about half of median septum length). The muscle scars are very well developed and include deep and rounded anterior adductors. The brachial ridges in the adult specimens are raised and formed by large endoespines. The anterior portions of these ridges are curved toward the anterior end of the median septum. The rest of the interior of the valves has few large endospines that tend to be arranged in radial lines. Along the commisure the endospines are thinner, longer and more numerous.

\section{Remarks}

Neochonetes pegnonensis sp. nov. is similar to $N$. (Sommeriella) hockingi Archbold, 1991, from the Aktastinian Wooramel Group, Carnarvon Basin, Western Australia. They present similarities in shell size, outline and internal morphology of the dorsal valve, but both species differ in the capillae density. Neochonetes (Sommeriella) obrieni Archbold, 1995, from the Tastubian Wye Worry Member of the Carolyn Formation (Canning Basin, Western Australia), presents the same density of capillae as the Argentine species, but differs in shell size and outline. Other similar small-sized species are N. (Sommeriella) hardmani Archbold, 1993, and N. (S.) robustus Archbold, 1981, both from the Permian of Western Australia; with the first species, N. pegnonensis sp. nov. differs in detail of the ornament and in the development of the sulcus and fold, and with the second species, in shell outline.

Figure 3. a-g. Streptorhynchus? sp. a, external mould of dorsal valve, IPI 3133, x3. b, external mould of dorsal valve, IPI $3130 \mathrm{~b}, \mathrm{x} 3$. c, d, internal and external mould of dorsal valve, IPI 3127a-b, x3. e, internal mould of dorsal valve, IPI 3126a, x3. f, internal mould of dorsal valve, IPI 3129, x3. g, internal mould of ventral valve, 3132a, x3.5. h-o. Neochonetes pegnonensis sp. nov. h, internal mould of ventral valve, IPI 2959, x3. i, external mould of dorsal valve, IPI 2978, x4. j, internal mould of ventral valve, IPI 2960, x3.5. k, internal mould of ventral valve, IPI 2957, x3.5. 1, internal mould of ventral valve, IPI 2977, x4. m, dorsal interior, IPI 2969, x3. n, external mould of dorsal valve, IPI 2964, x3. o, ventral valve exterior, IPI 2966, x3.5. p-u. Tivertonia jachalensis (Amos). p, internal mould of ventral valve, IPI 2951, x3.5. q, partially decorticated ventral valve, IPI 2943, x3. r, internal mould of ventral valve, IPI 2953, x3. s, partially decorticated ventral valve, IPI 2941, x3. t, partially decorticated ventral valve, 2952a, x3. u, dorsal valve interior, IPI 2942, x3. 

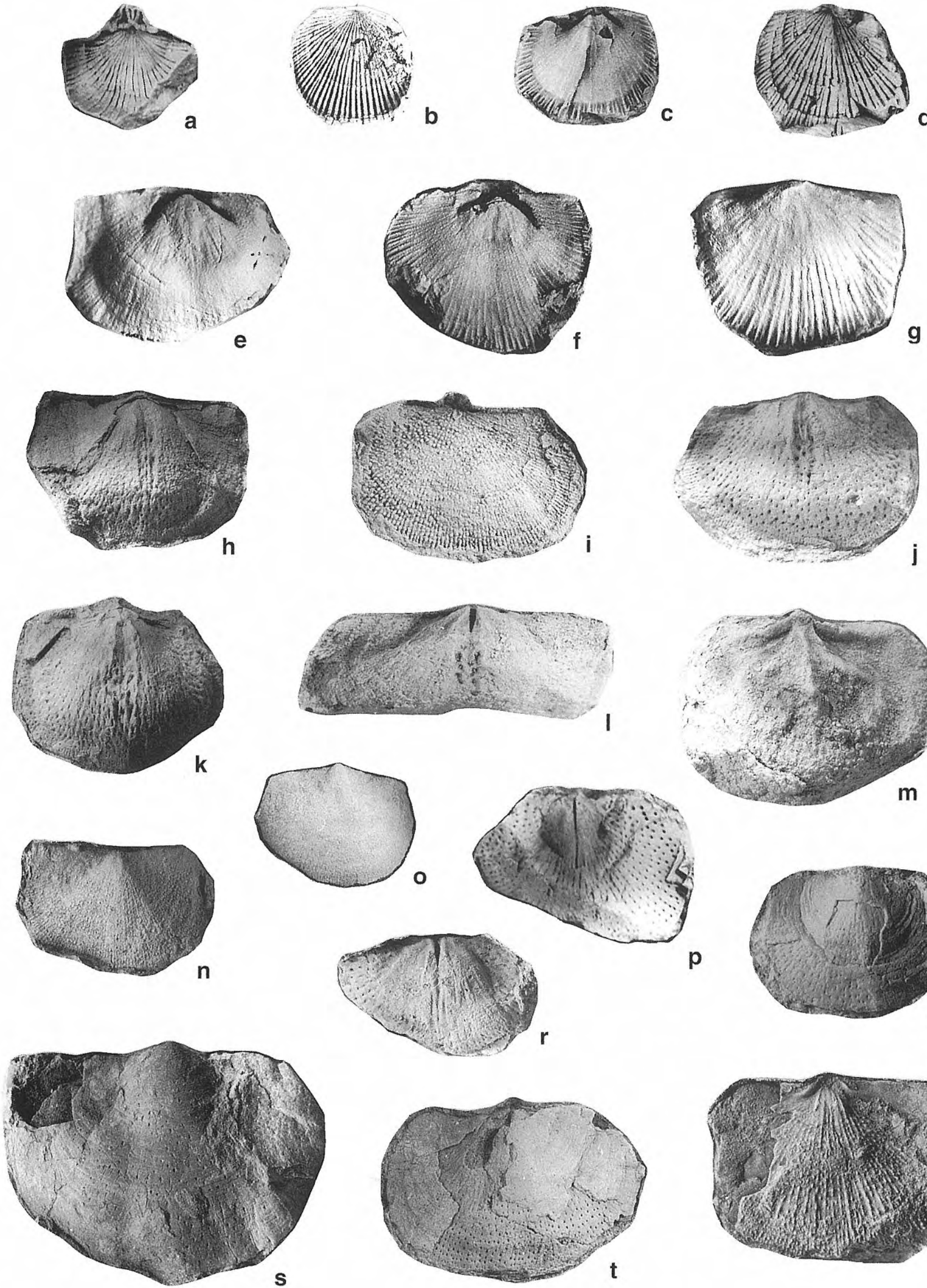

$p$
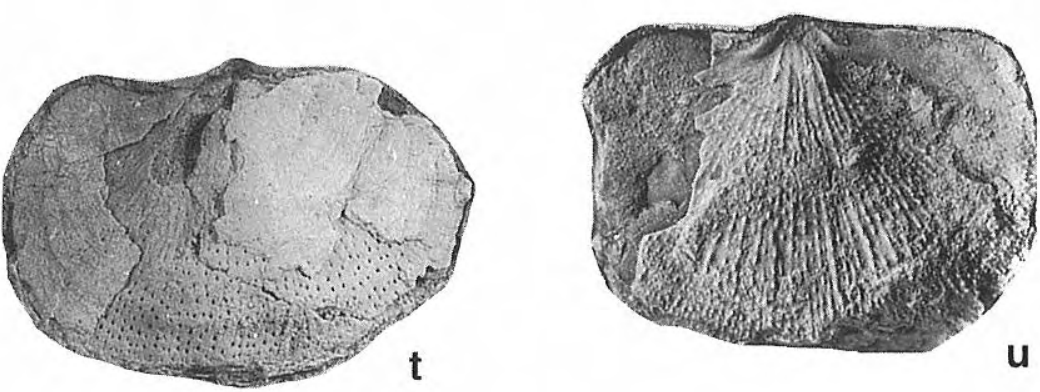


\section{Subfamily Svalbardiinae Archbold, 1982 Genus Tivertonia Archbold, 1983}

Type species: Lissochonetes yarrolensis Maxwell, from the Yarrol Formation in Eastern Australia (Sakmarian).

\section{Diagnosis}

Shell smooth to pseudocapillate, concavo-convex, maximum width at mid-length of shell, sulcus poorly defined or absent, cardinal spines short, forming a moderate angle with the hinge line; interior of the brachial valve with a pit, median septum long.

Geographical and stratigraphical distribution: Early Permian of Australia, Himalayas and Argentina.

\section{Discussion}

The inclusion of Lissochonetes breviseptum Amos, 1961, in Tivertonia by Archbold and Gaetani (1993) can't be supported. Most of the specimens housed in the fossil invertebrate collection at the La Plata Museum, which were studied by Amos himself and included in Lissochonetes breviseptum, show features completely opposed to Tivertonia and probably belong to genus Gatia Archbold, 1993; other specimens were included in the productid Aseptella patriciae Simanauskas, 1996. The material illustrated by Pujanas (1989) does not belong to Lissochonetes breviseptum, and probably can be included in the genus Neochonetes.

\section{Tivertonia jachalensis (Amos, 1961)}

Fig. 3 p-u

1945 Chonetes scitula Leanza, 280-284, pl. 1, figs. 1-9.

*1961 Lissochonetes jachalensis nom. nov.; Amos, 83-84.

1991 Lissochonetes jachalensis Amos; Simanauskas, 136, pl. 1, fig. 13.

Locality: Western limb of the Rincón Blanco syncline, 35 km west of Jagüié, La Rioja province.

Stratigraphic horizon: Río del Peñón Formation, middle member, horizons $6 \mathrm{a}$ and $6 \mathrm{~b}-\mathrm{c}$.

Material: Six ventral valves (IPI 2941, 2943, 2945, 2946, 2949, 2952a); one dorsal interior (IPI 2942); one external mould of dorsal valve (IPI 2944); two internal moulds of ventral valves (IPI 2951, 2953); two internal moulds of dorsal valves (IPI 2950-2955). Several fragments of internal and external moulds (IPI 2956). All material is from the horizon $6 \mathrm{~b}-\mathrm{c}$.

\section{Remarks}

Archbold and Gaetani (1993) recently removed this species from Lissochonetes and placed it in Tivertonia. This new placement is correct only for the specimens from the type locality of the species, Quebrada de la Herradura, San Juan province, Argentina (Leanza, 1945) and for those described herein.

\section{Description}

Exterior: Shell concave to plano-convex, slightly wider than long; width of the hinge line shorter than the maximum width, which is measured at mid-length of shell. Cardinal extremities blunt and rounded. Surface smooth, with very fine growth lines and bases of spinules. Partially decorticated specimens show a pseudocapillate surface.

Interior: Ventral interior with a long median septum, extending to about mid-length of the valve; it is higher and thinner in its anterior part and slightly wider at its posterior end. A shallow and parallel ridge is observed at both sides of the anterior portion of the median septum. Vascular trunks not observed. The adductor muscle scars are smooth and elongated. Diductor muscle scars anteriorly striated, reaching to about mid-length of valve. The rest of the shell carries very small and numerous endospines, arranged in radial lines. The interior of the dorsal valve shows a tetralobate cardinal process with a pit at its base. The socket ridges are weak and short. In front of the cardinal pit there is a very thin and long median septum; in some specimens it is barely distinguished, as is the case also with the brachial ridges. The rest of the interior shows numerous rows of small endospines.

\section{Discussion}

The studied specimens differ only slightly from the type material of Tivertonia jachalensis from Quebrada de la Herradura, San Juan province, Argentina (Leanza, 1945). The interior of this species is similar to that of the type species of Tivertonia, but they can be differentiated by their size and the external appearance of the shell. The Argentine species resembles Tivertonia chumukensis Archbold and Gaetani, 1993, from the lower Permian of the northwestern Himalayas, by their size. However, the shape of the brachial ridges is different in both species. $T$. jachalensis can be separated from $T$. tatamariensis Singh and Archbold, 1993, by the absence of a sulcus and less transverse outline. T. pillahuinsensis (Harrington, 1955), from the lower Permian Bonete Formation of the Sierras

Figure 4. a-f. Dyschrestia? sp. a, f, internal and external moulds of ventral valve, IPI 3097a-b, x2.5. b, internal mould of ventral valve, IPI 3103a, x3.5. c, internal mould of ventral valve, IPI $3106 \mathrm{~A}$, x3. d, external mould of ventral valve, IPI 3098, x2. e, fragment of external mould of ventral valve, IPI 3104, x3.5. g-l, n. Kochiproductus riojanus (Leanza). g, incomplete ventral valve, IPI 3175, x1.5. h, ventral view of fragmentary articulate specimen, IPI 3171a, x1,5. i-j articulate specimen, lateral and dorsal view, PIL, 10502, x1. k, external mould of dorsal valve, IPI 3169a, x1. 1, n, articulate specimen, ventral and dorsal view, IPI 3169b, x1. m, o-r. Costatumulus sp. A. m, external mould of dorsal valve, IPI 3111, x3.5. o, ventral valve exterior, IPI 3110, x3. p, external mould of dorsal valve, IPI 3107b, x3.5. q, external mould of dorsal valve, IPI 3114, x4. r, external mould of dorsal valve, IPI $3109, x 3$. 

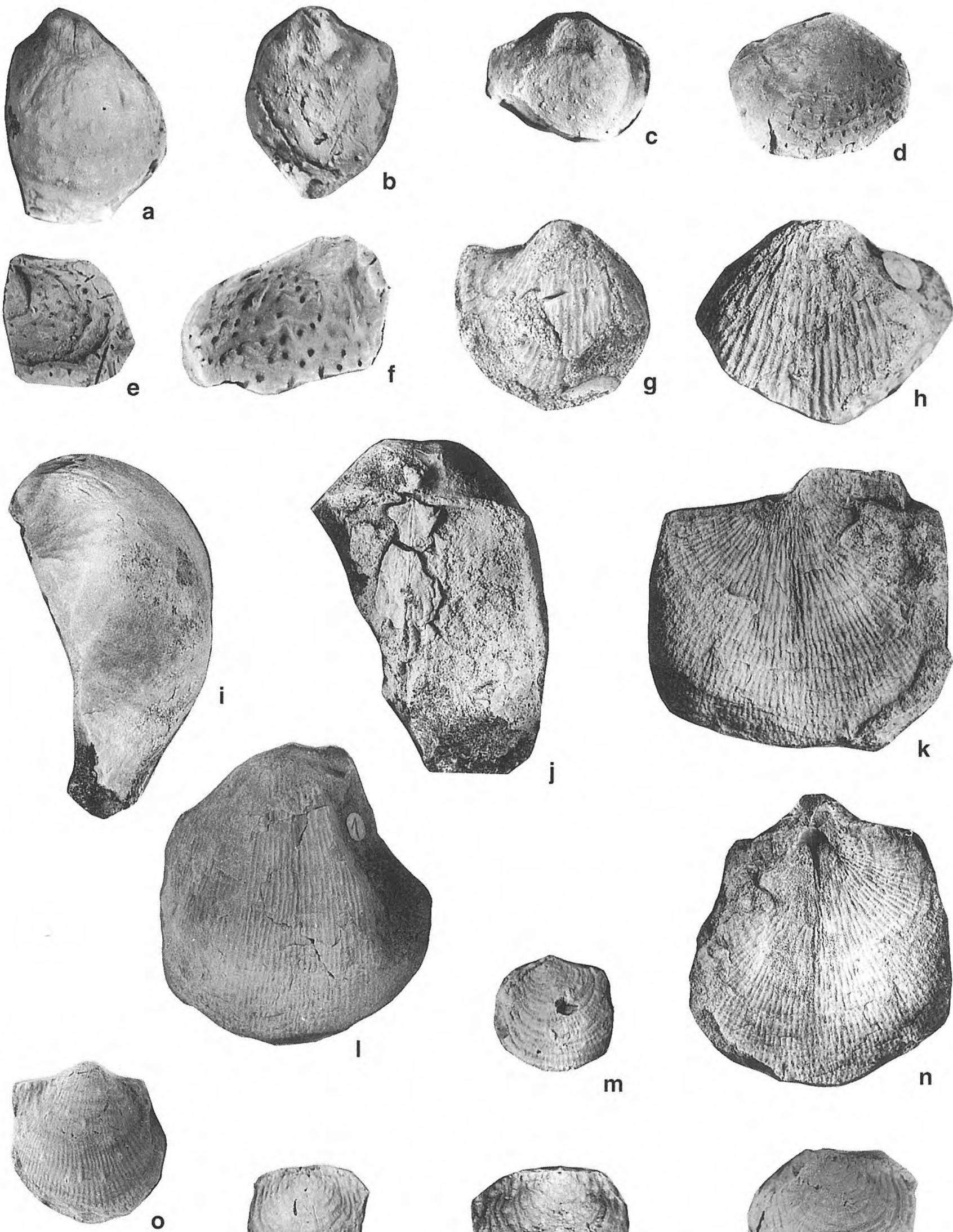

m
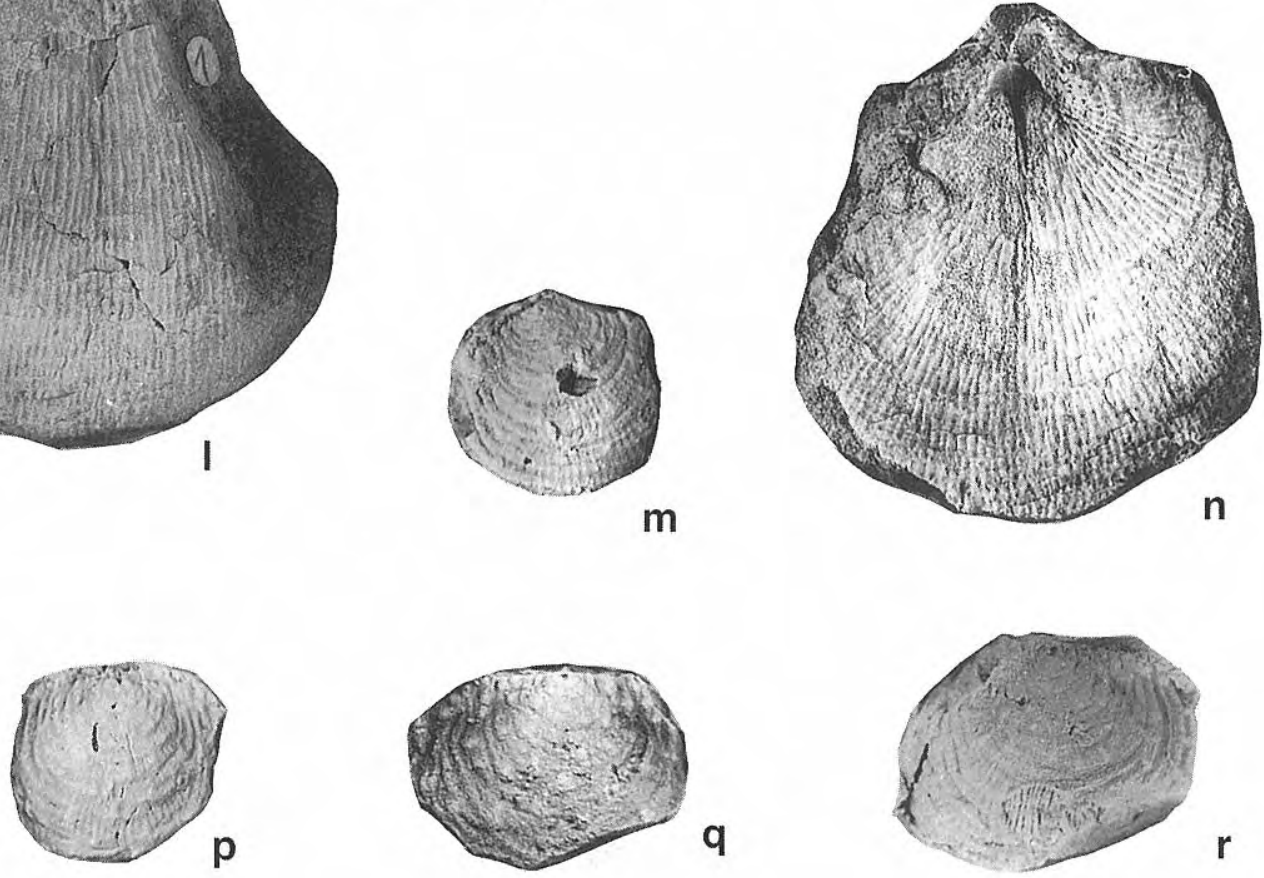
Australes of Argentina, is clearly different from $T$. jachalensis. The Bonete Formation species is robust, more round and with internal features very pronounced, rather similar to specimens of $T$. yarrolensis from the Farley Formation in eastern Australia, illustrated by Archbold (1986).

Suborder PRODUCTIDINA Waagen, 1883

Superfamily PRODUCTOIDEA Gray, 1840

Family Productellidae Schuchert, 1929

Subfamily Overtoniinae Muir-Wood and Cooper, 1960 Genus Dyschrestia Grant, 1976

Type species: Dyschrestia spodia Grant, 1976, from the Permian of southern Thailand.

\section{Dyschrestia? sp. Fig. 4 a-f}

Locality: Eastern limb of the Rincón Blanco syncline, left bank of the Río del Peñón, 35 km west of Jagüé, La Rioja province.

Stratigraphic horizon: Río del Peñón Formation, lower member, horizons 5 ' and 6'.

Material: Seven internal moulds of ventral valves, three of them with their matching external moulds (IPI 3097a-b, 3098a-b, 3099, 3100, 3103a-b, 3106A and 3106B); one fragmentary external mould of a ventral valve (IPI 3104); one fragmentary ventral valve partially decorticated (IPI 3106C); one fragmentary external mould of a dorsal valve (3106D); one poorly preserved internal mould of dorsal valve with its matching external (3102a-b). All material from the horizon $6 '$.

\section{Description}

Small shell with moderately convex ventral valve, ornamented with numerous small spines (density of c. 3 spines per $4 \mathrm{~mm}^{2}$ at about mid-length), that are randomly distributed over the entire shell surface. Conspicuous growth lines (density c. 8 to 9 per $\mathrm{mm}$ at anterior margin). Ventral interior showing a small muscle scar divided in two subtriangular areas by a weak median ridge. Dorsal valve very poorly preserved. The only features observed are the moderate concavity of the valve, weak growth lines and, internally, a bilobate cardinal process and a poorly preserved median septum. Other characters unknown.

\section{Discussion}

External features of the ventral valve indicate Dyschrestia, or an allied genus. However, this assignment can only be provisional due to the poor preservation of the material studied, fundamentally the lack of better information concerning the dorsal valve. In fact, Dyschrestia is very close to Krotovia Fredericks in the external features but possess a more strongly developed dorsal median septum.

Family Productidae Gray, 1840

Subfamily Buxtoniinae Muir-Wood and Cooper, 1960

Tribe Buxtoniini Muir-Wood and Cooper, 1960, sensu Brunton, Lazarev \& Grant, 1995

Genus Kochiproductus Dunbar, 1955

Type species: Productus porrectus Kutorga, 1844.

\section{Remarks}

Kochiproductus includes a number of large to gigantic buxtoniids widely distributed in Permian rocks, characterised by external ornament of simple radiating costae interrupted by elongate "ramps" (Shi and Waterhouse, 1996). It is very similar to Buxtonia and can be separated from it by a marked reticulation on the dorsal visceral disc and, interiorly, because the dorsal median septum lacks a bifid base (Sarytcheva, 1968). However, the posterior part of the dorsal median septum, generally bifurcated in Buxtonia, appears to be nothing else as the ridges developed in connection with the base of the cardinal process (Likharev, 1938). Thus, it seems preferable to emphasise the differences in external ornament.

\section{Kochiproductus riojanus (Leanza, 1948) \\ Fig. 4 g-l, n}

*1948 Productus riojanus Leanza, 240-242, pl. 1, figs. 1, 2, 5 .

1972 Buxtonia riojana (Leanza); Antelo, 167, pl. 167168, figs. 3, 5, 7, 8 .

1979 Buxtonia riojana (Leanza); Amos, 76, figs. A-C.

Locality: Western limb of the Rincón Blanco syncline, 35 $\mathrm{km}$ west of Jagüé, La Rioja province.

Figure 5. a-d. Costatumulus sp. B. a-b, external and internal mould of ventral valve, IPI 3176a1-b1, x2. c, dorsal view of articulate specimen, 3181a, x2. d, external mould of dorsal valve, IPI 3181b, x2. e-l. Costatumulus sp. C. e-f, ventral valve, ventral and lateral view, IPI 3060, x2. g, ventral valve, IPI 3392, x2. h, detail of the ventral exterior, IPI 3055 , x2.5. i, external mould of dorsal valve, IPI 3389, x2.5. j, external mould of dorsal valve, IPI 3058a, x2.5. k, incomplete ventral valve, IPI 3061, x2.5. 1, detail of the ventral exterior, IPI 3056, x2,5. m-v. Rhynchopora sp. m, external mould of ventral valve, IPI 3375, x2. n, internal mould of dorsal valve, IPI 3374a, x2. o, internal mould of articulate specimen, anterior commissural view, IPI 3367, x2. p, internal mould of ventral valve, IPI 3364, x2. q, external mould of ventral valve, IPI 3371, x2. r, internal mould of articulate specimen, IPI 3362, x2. s, internal mould of ventral valve, IPI 3361, x2. t-u, internal mould of dorsal valve, IPI 3372a, x3, detail x10. v, internal mould of dorsal valve, IPI 3373a, x2. 

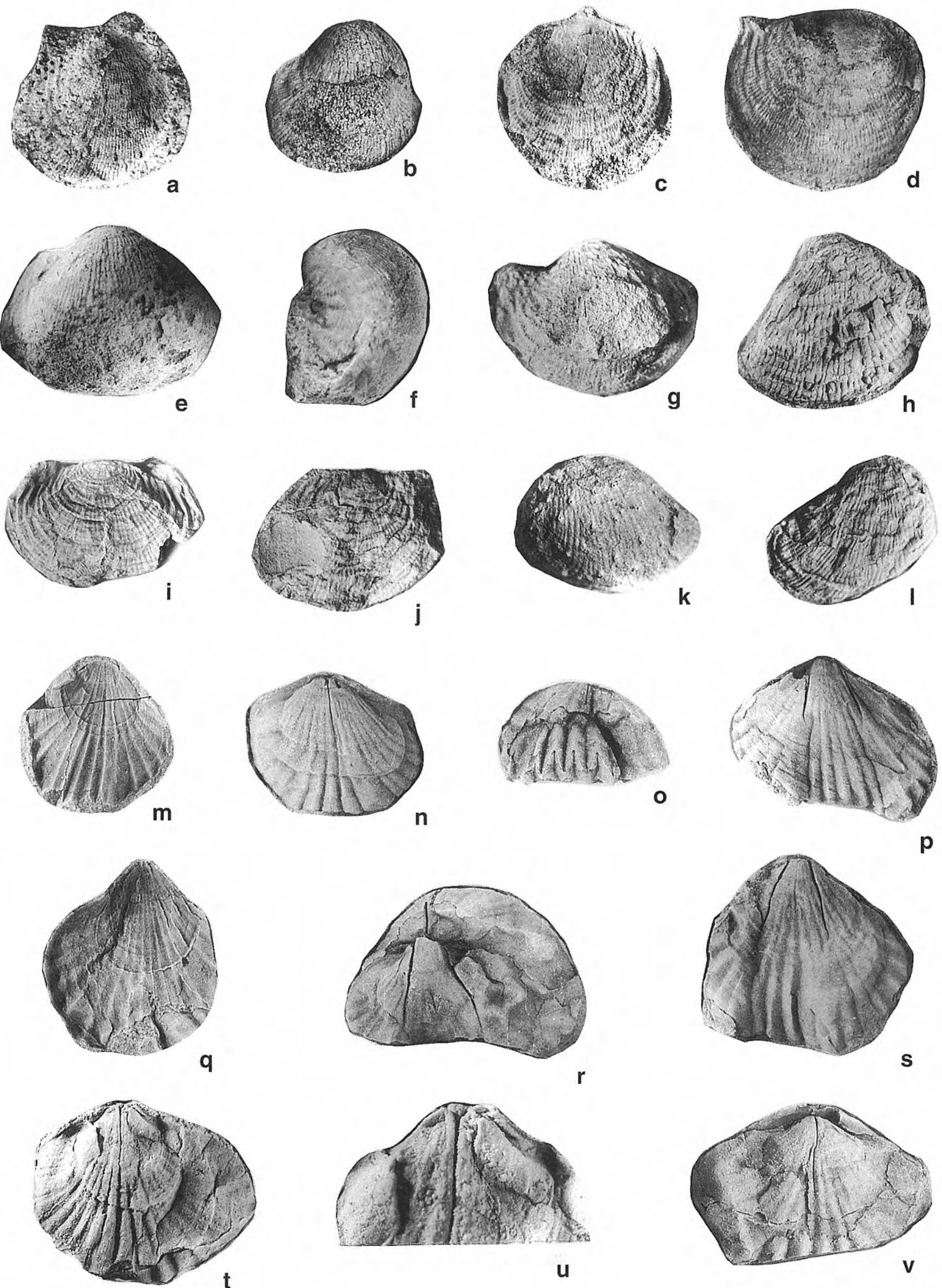

u 
Stratigraphic horizon: Río del Peñón Formation, middle member, horizon 6 a.

Material: Three articulate specimens, one of them incomplete (IPI 3169b, 3171a; PIL 10502); two internal moulds of ventral valves (IPI 3172 and 3174); two incomplete external moulds of dorsal valves (IPI 3169a and $3171 \mathrm{~b}$ ); two incomplete ventral valves (IPI 3173 and 3175); several fragments of internal and external moulds.

\section{Description}

Shells plano-convex, medium to large, slightly elongate in outline. Ventral valve moderately to strongly convex with umbonal region strongly swollen; umbo strongly incurved over the hinge line; umbonal angle c. $90^{\circ}$. Ears inconspicuous in juvenile specimens and unknown in mature specimens. Median sulcus distinct, commencing about $20 \mathrm{~mm}$ from the umbo and well defined only at midlength of valve. Lateral slopes high, almost vertical set. Ventral ornament of distinct costae and inconspicuous rugae. Costae (10 to 12 in $10 \mathrm{~mm}$ at mid-length) are interrupted by elongate swollen nodes ("ramps"), corresponding to spine bases. Internal characters of the ventral valve unknown. Dorsal valve with flat visceral disc and short trail. Pattern of costae similar to the ventral valve; distinct concentric rugae, crossing the costae and producing a reticulation; small and abundant spines crowded on anterior trail. Interior with a bilobate cardinal process in ventral view; conspicuous median septum that reaches two thirds of the valve length and buttress plates fused with the posterior end of the median septum. Other internal characters unknown.

\section{Discussion}

The characters observed in the available material identify it as Productus riojanus, as described by Leanza (1948, p. 240, pl. 1, figs. 1, 2 and 5). This author worked with material from the same levels of the Río del Peñón Formation, from which we obtained our specimens.

Productus riojanus Leanza was later included in Buxtonia Thomas by Antelo (1972, p. 167, pl. 1, figs 3-4, 7-8) when studying the brachiopods from the Quebrada Larga Formation. Also, he included in this assignation specimens from the Río del Peñón Formation housed in the Miguel Lillo Institute of Tucumán, Argentina (collection number PIL 10502). However, the revision of the material studied by Antelo, part of which is re-figured in this paper (Fig. $4 \mathrm{i}-\mathrm{j}$ ), suggests its inclusion in the genus Kochiproductus.

Kochiproductus riojanus has been compared by some authors (Leanza, 1948; González, 1993) with the South American species Kochiproductus peruvianus (d'Orbigny), described from the Asselian Copacabana Formation of Bolivia (Kozlowski, 1914, p. 38, pl. 4, figs. 1-4; Chronic, in Newell et al., 1953, p. 83, pl. 3-4). However, Kochiproductus riojanus is slightly more elongate with deeper sulcus and vertical lateral slopes, in relation to Kochiproductus peruvianus (d'Orbigny). Also, the Argentine species shows a different ornamentation with finer costae.
Superfamily LINOPRODUCTOIDEA Stehli, 1954

Family Monticuliferidae Muir-Wood and Cooper, 1960

Subfamily Auriculispinae Waterhouse, 1986

Genus Costatumulus Waterhouse, 1983

Type species: Auriculispina tumida Waterhouse in Waterhouse et al., 1983.

\section{Remarks}

Considering the last emended diagnosis of Costatumulus, this genus includes "linoproductidae with variably arched ventral valve and evenly concave dorsal valve; ventral ornament of fine costellae, very low, narrow rugae, recumbent spines set on distinct spine ridges, and narrow band of spines alongside hinge. Dorsal ornament of fine costellae and dimples but no spines. Ventral adductor scars smooth in early maturity, later becoming posteriorly striated and ultimately dendritic" (Briggs, 1998, p. 155).

Two genera closely related to Costatumulus are Cancrinella Fredericks and Magniplicatina Waterhouse. From the first one it can be differentiated by the absence of spines on the dorsal valve and from the second by the lack of strong rugae.

In Argentina, some species of Costatumulus have originally been referred to Cancrinella. Archangelsky and Lech (1985) and Sessarego and Lech (1985) mentioned the presence of Cancrinella aff. farleyensis from the Del Salto and Santa Helena formations (Calingasta-Uspallata Basin). Also, Lech (1990) mentioned Cancrinella farleyensis from the Agua del Jagüel Formation (Calingasta-Uspallata basin) and Lech and Aceñolaza (1987) described Cancrinella sp. from the Río del Peñón Formation (Río Blanco Basin). Recently, Taboada (1998) described Costatumulus amosi sp. nov. from the Agua del Jagüel Formation at different localities of the Uspallata area (Calingasta-Uspallata Basin).

Our material referred to Costatumulus is scarce and fragmentary. This prevents adequate specific identification. However, sufficiently clear external differences allow to discriminate three species in the Río del Peñón Formation and to compare them with material from other regions.

\section{Costatumulus sp. A}

Fig. 4 m, o-r

Locality: Eastern limb of the Rincón Blanco syncline, 35 km west of Jagüé, La Rioja province.

Stratigraphic horizon: Río del Peñón Formation, lower member, horizons 5 ' and 6'.

Material: Five external moulds of dorsal valves (IPI 3107b, $3109,3111,3112,3114)$; two internal mould of dorsal valves (3107a, 3108); one ventral valve (IPI 3110). All material from horizon 6'. 


\section{Description}

Small shell with length and maximum width about equal; ventral valve slightly convex; regularly curved lateral profile, umbo incurved and ears small. Ornamentation of fine costellae ( 3 to 4 per millimeter on the median-anterior region) and few irregularly distributed spines. The spine bases suggest that they must have grown at a low angle to the surface. Rugae are weak, slightly stronger on the ears. On a few fragments it is possible to observe "spine bunches" on the ears. However, we are not sure if this fragmentary material belongs to the same taxon (i.e. Costatumulus sp. A). Dorsal valve gently concave, with costellae and rugae. The rugae are significantly stronger than on the ventral valve, especially on the ears. Others features unknown.

\section{Discussion}

Costatumulus sp. A is characterised by its small size, shell approximately as wide as long and ventral valve gently convex. These features are comparable with those observed in Costatumulus parva (Cooper and Grant, 1975, p. 1153 , pl. 428, figs. 19-40), from the lower Permian of Texas (Neal Ranch and Skinner Ranch formations). Likewise, both species are closely comparable in the number of costellae and the spine arrangement. Unfortunately, the material described herein is not well enough preserved to corroborate the identity of both taxa.

\section{Costatumulus sp. B}

Fig. 5 a-d

1987 Cancrinella sp. Lech and Aceñolaza, 108, figs. 2a-c.

Locality: Western limb of the Rincón Blanco syncline, 35 km west of Jaguié, La Rioja province.

Stratigraphic horizon: Río del Peñón Formation, middle member, horizon 6 a.

Material: Two internal moulds of ventral valves (IPI $3176 \mathrm{a} 1$ and $3176 \mathrm{a} 2$ ); one external mould of ventral valve (IPI 3176b1); one incomplete ventral valve partly decorticated (IPI 3180); one articulate specimen partly decorticated (IPI 3181a); three poorly preserved external moulds of dorsal valves (IPI 3178, 3179 and 3181b).

\section{Description}

Small concavo-convex shells with slightly elongate outline; hinge width slightly narrower than maximum width, which is measured at mid-length of shell. Ventral valve moderately convex with prominent umbonal region and incurved umbo. Costellae fine, about 2-3 in $1 \mathrm{~mm}$ (measured at anterior half of the valve) and weak rugae which are slightly more conspicuous on the ears. Costellae carry randomly distributed spines, with a density of about 4-5 spines per $25 \mathrm{~mm}^{2}$ (near anterior margin of the valve). The ears carry a double row of spines, slightly larger than the body spines. Dorsal valve gently concave, with a similar ornament to the ventral one but without spines and with stronger rugae. Other shell features unknown.

\section{Discussion}

The specimens described herein come from the same fossil bed from which Lech and Aceñolaza (1987, p. 108, figs. 2a-c) identified Cancrinella sp. As far as can be inferred from their fragmentary material, it appears to be conspecific with ours.

Costatumulus sp. B is larger and more convex than Costatumulus sp. A, described from the lower member of the Río del Peñón Formation.

Although inadequate for detailed comparison, Costatumulus sp. B is close to C. sparsispinosus (Cooper and Grant, 1975, p. 1154, pl. 430, figs. 15-47) from the lower Permian of Texas (Bone Spring and Skinner Ranch formations) and C. irwinensis Archbold (1983, p. 240, figs. 1P-C) from the Sakmarian of Western Australia (Callytharra Formation and Fossil Cliff Member), in details of costellae. However, both species show different general shell morphology in relation with Costatumulus sp. B. Also, the Australian species is much larger than the Argentine one.

\section{Costatumulus sp. C}

Fig. 5 e-1

Locality: Western limb of the Rincón Blanco syncline, 35 $\mathrm{km}$ west of Jagüé, La Rioja province.

Stratigraphic horizon: Río del Peñón Formation, middle member, horizon 11 .

Material: Seven incomplete ventral valves (IPI 3054, 3055, 3056, 3060, 3061, 3062 and 3392); one incomplete dorsal valve with its matching external mould (IPI 3058a-b); one external mould of dorsal valve (IPI 3389). Additional material with number IPI 3016.

\section{Description}

Small shell, rounded to transverse in outline, with the maximum width at about mid-length of shell. Ventral valve strongly convex with incurved umbo. Ears relatively small and sharp. Ornament of fine costellae (5 to 6 in $2 \mathrm{~mm}$ at mid-length of valve) and gentle rugae. Rugae significantly stronger over the ears. Spines reaching a density of 6 to 7 per $25 \mathrm{~mm}^{2}$, measured at mid-length of valve. The spines exhibit a low angle with the valve surface; on the ears they are grouped into "bunches". Dorsal valve flat to slightly concave, ornamented with costellae and rugae, that are notably more conspicuous than in the ventral valve, becoming wavy on the ear region. Internal features unknown.

\section{Discussion}

In relation to Costatumulus sp. A and Costatumulus sp. B described from the Río del Peñón Formation, Costatumulus sp. C is distinctively more convex. Compared with Costatumulus sp. A, Costatumulus sp. C is notably larger and it shows a greater density of costellae and spines than Costatumulus sp. B. 
Costatumulus irwinensis Archbold, 1983, has a strongly convex ventral valve like Costatumulus sp. C but the Australian species is larger.

Compared with Cancrinella villiersi (d'Orbigny) from the lower Permian Tarma Group of Perú (Chronic, in Newell et al., 1953, p. 89, pl. 6, figs. 10-14), Costatumulus sp. C has a strongly convex ventral valve with strongly incurved umbo but both species are rather close in details of costellae and rugae.

\section{Order RHYNCHONELLIDA Kuhn, 1949} Superfamily RHYNCHOPOROIDEA Muir-Wood, 1955

Family Rhynchoporidae Muir-Wood, 1955 Genus Rhynchopora King, 1865

Type species: Terebratula geinitziana de Verneuil, 1845. Late Permian, northern Russian platform.

\section{Remarks}

The diagnosis of the genus has been revised by Erlanger (1981), using topotypical material of the type species from the Archangel province (European Russia), Kazanian Stage, upper Permian.

Rhynchopora is known from the Devonian, Carboniferous and Permian of Europe, Asia, North Africa, America and Australia. This is the first record from Argentina.

\section{Rhynchopora sp.}

Fig. $5 \mathrm{~m}-\mathrm{v}$

Locality: Western limb of the Rincón Blanco syncline, 35 $\mathrm{km}$ west of Jagüé, La Rioja province.

Stratigraphic horizon: Río del Peñón Formation, middle member, horizon 11.

Material: Five internal moulds of ventral valves (IPI 3361, $3364,3376,3382,3384)$; five internal moulds of articulated specimens (IPI 3362, 3365, 3366, 3367, 3368); three external moulds of ventral valves (IPI 3363, 3371, 3375); eleven internal moulds of dorsal valves (IPI 3369, 3370, 3372a, 3373a, 3374a, 3378a, 3379, 3380, 3381, 3383, 3385); six external moulds of dorsal valves (IPI 3372, 3373b, 3374b, 3377, 3378b, 3379b); additional internal and external ventral and dorsal moulds (IPI 3386).

\section{Description}

Exterior: Medium size, subtriangular to rounded in outline. Maximum width slightly anterior to the mid-length of shell. Ventral valve gently convex with greatest convexity at umbo; beak pointed and strongly recurved; sulcus shallow commencing from mid-length and widening anteriorly up to about $2 / 3$ of the maximum width. Dorsal valve more inflated, with a very gentle middle fold that is barely distinguishable from the lateral flanks. Sulcus and fold carrying about 5 costae and the lateral flanks 6 costae each. Costae start from umbo, posteriorly fine and becoming wider towards the anterior margins; on the postero-lateral margins they are barely noticeable. Surface with fine concentric growth lines; punctae coarse up to 5 or 6 per mm anteriorly.

Interior: Dental plates distinct, divergent about $20^{\circ}$, reaching up to $1 / 3$ of the valve length. Dorsal interior with small septalium supported by a distinct median septum that extends to mid-length of valve. Dental sockets slightly crenulate. Other internal structures unknown.

\section{Discussion}

The described material is larger than the specimens of the type species Rhynchopora geinitziana studied by Erlanger (1981, p. 66, pl. 9, figs. 1-10). Also, our material shows fewer costae on the flanks in relation with the specimens described by Erlanger.

Rhynchopora $\mathrm{sp}$. is very close to $R$. australasica Archbold, described from the Asselian horizons of the Lyons Group in the Carnarvon Basin, Western Australia (Archbold, 1995, p. 110, figs. 8F-R), which is however larger. Both species have similar external and internal morphological features.

Specimens of $R$. culta Waterhouse described from the Tastubian faunas of Peninsular Thailand (Waterhouse, 1982 , p. 345 , pl. 2, fig. 6-11) and from the upper Sakmarian fauna of western Malaysia (Shi and Waterhouse, 1991), show the same kind of crenulate dental sockets as our specimens. However, $R$. culta has a more inflated shell with a more trigonal outline and stronger costae than Rhynchopora sp.

Also, R. arctica Licharev and Einor (in Abramov and Grigorieva, 1983, p. 110-111, pl. 15, fig. 12-17) is close to Rhynchopora sp. in its external features of size and shape.

In comparison with South American species described from the Tarma Group, Perú (Chronic in Newell et al., 1953), Rhynchopora sp. appears to be close to $R$. aff. illinoisensis (Worthen) (Chronic in Newell et al., 1953, p.

Figure 6. a-i. Trigonotreta riojanensis (Lech). a, internal mould of ventral valve, IPI 3153, x2. b, internal mould of articulate specimen, ventral view, IPI 3168, x2. c, ventral valve, IPI 3164, x2. d, internal mould of articulate specimen, dorsal view, IPI 3152, x1. e, internal mould of ventral valve, IPI 3155a, x2. f, internal mould of articulate specimen, dorsal view, IPI 3151, x1.5. g, ventral valve, IPI 3157, x2. h, external mould of ventral valve, IPI 3154, x2. i, incomplete ventral valve, IPI 3163, x1. j-r. Trigonotreta sp. j, internal mould of ventral valve, IPI $3120, x 1.5$. $\mathrm{k}$, external mould of dorsal valve, IPI 3125A', x3. 1, detail of costae, 3125E, x2. m, p, internal and external mould of ventral valve, IPI 3125B (x4)-B' (x3.5). n, internal mould of articulate specimen, dorsal view, IPI 3125C, x2. o, internal mould of ventral valve, IPI $3116, x 1.5$. q, internal mould of ventral valve, IPI 3115, x1.5. r, internal mould of articulate specimen, dorsal view, IPI 3117, x1.5. 

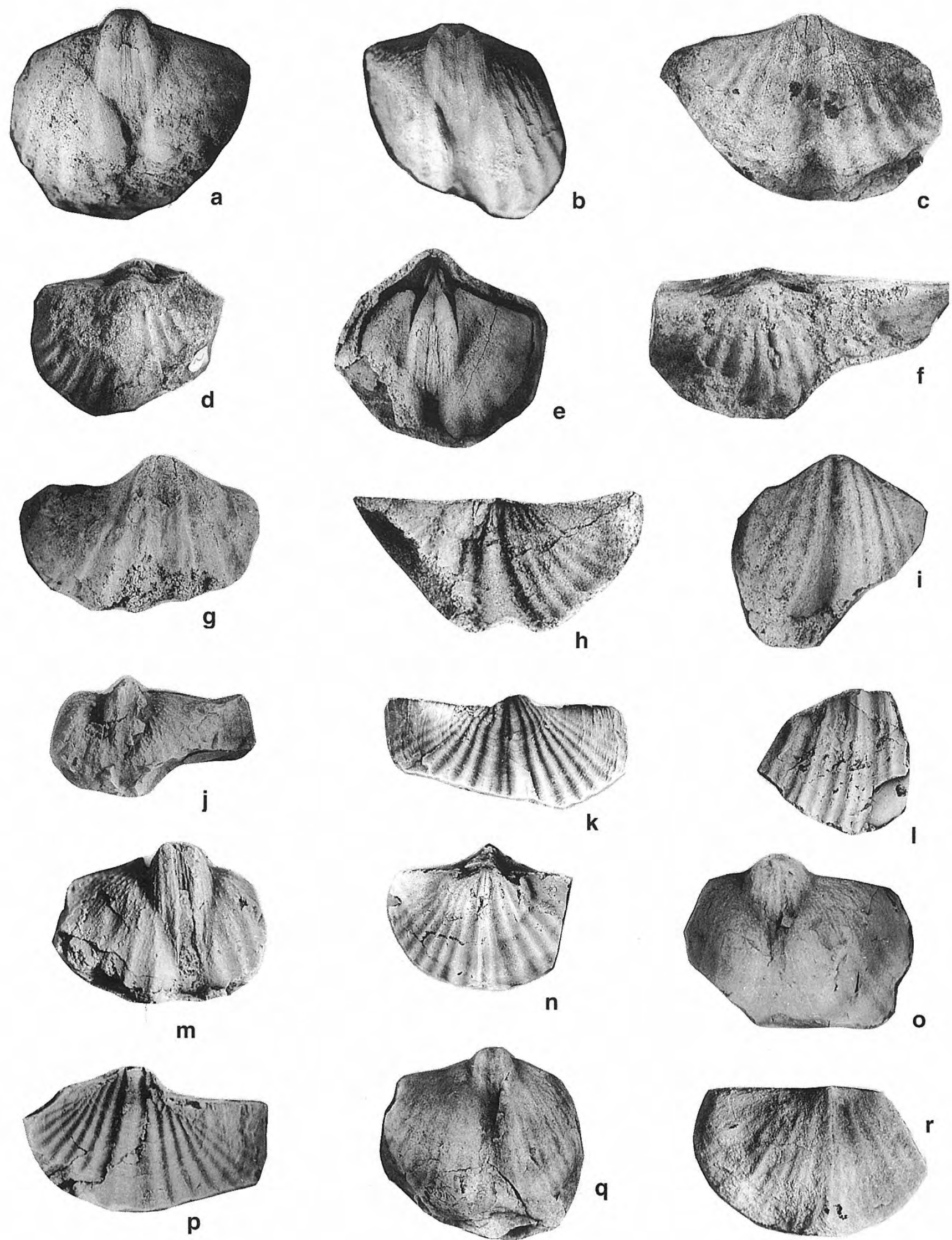
94-95, pl. 17, fig. 1a-3b). General morphology of the shell and internal features are rather similar in both species. However, $R$. aff. illinoisensis is rather smaller and possesses a greater number of costae than Rhynchopora sp.

Order SPIRIFERIDA Waagen, 1883

Suborder SPIRIFERIDINA Waagen, 1883

Superfamily SPIRIFEROIDEA King, 1846

Family Trigonotretidae Schuchert, 1893

Subfamily Trigonotretinae Schuchert, 1893

Genus Trigonotreta Koenig, 1825

Type species: Trigonotreta stokesii Koenig, 1825. Early Permian of Tasmania.

\section{Remarks}

The diagnosis of Trigonotreta was discussed by Clarke (1979) when redescribing the type species. The genus includes medium to large non-punctate spiriferids with lateral fasciculate costae and without delthyrial plate but with the apex of the delthyrium usually blocked by a bulbous pedicle callist; dental plates and ventral cardinal region heavily thickened by callus (Clarke, 1979). Related genera also included in the Subfamily Trigonotretinae were discussed by Archbold and Thomas (1984) and Archbold (1991).

Trigonotreta was recorded from the Permian of Australia (Thomas, 1971; Archbold and Thomas, 1986; Archbold, 1995), India (Sahni and Dutt, 1959; Waterhouse and Gupta, 1978; Singh and Archbold, 1993; Archbold et al., 1996) and from other peripheral Gondwanan regions such as the Baoshan Block (Shi et al., 1995, 1996), Selong (Shi and Shen, 1997), Oman (Angiolini et al., 1997) and recently from Northern Peninsular Thailand (Archbold, 1999).

In Argentina, Leanza (1945) described Spirifer (Spirifer) pericoensis from the Tupe Formation, Quebrada de la Herradura locality (Paganzo Basin). We have studied conspecific material from the same locality and re-assign Leanza's species to Trigonotreta. Recently, Taboada (1999) regarded the occurrence of Trigonotreta occidentalis Thomas from the Permian of Patagonia (Mojón de Hierro Formation, Tepuel-Genoa Basin). However, this material wasn't described. Topotypic specimens of Trigonotreta occidentalis have been examined by one of us (G.C.) from the collections of the Australian Geological Survey Organisation. These specimens show characteristics clearly different from those of the Argentinean Trigonotreta species.

\section{Trigonotreta riojanensis (Lech and Aceñolaza, 1987)} Fig. 6 a-i

*1987 Punctothyris riojanensis Lech and Aceñolaza, 259260, pl. 2, fig. 8-9; pl. 3, fig. B.
Locality: Western limb of the Rincón Blanco syncline, 35 km west of Jagüé, La Rioja province.

Stratigraphical horizon: Río del Peñón Formation, middle member, horizon $6 \mathrm{a}$.

Material: Four articulate specimens, three of which are internal moulds (IPI 3151, 3152, 3158, 3168); three internal moulds of ventral valves (IPI 3153, 3155a, 3156); seven external moulds of ventral valves (IPI 3154, 3155b, 3159b, $3160,3161,3162,3167$ ); six incomplete ventral valves (IPI 3157, 3159a, 3163, 3164, 3165, 3166).

\section{Description}

Exterior: Shell of medium size, maximum width along the hinge line. Rate length/maximum width about 0.5 to 0.75. Angular cardinal extremities. Ventral valve more convex than dorsal one, with a prominent and strongly incurved umbo; umbonal angle about $90^{\circ}$ to $115^{\circ}$. Interarea low and moderately concave with distinctive denticle grooves and fine growth lines. Delthyrial angle about $60^{\circ}$. Sulcus narrow, widening towards the anterior margin $(1 / 6$ of maximum width of the valve). The sulcus is bounded by a costa on each side and the flanks show 6-7 costae. The costae are weakly fasciculated anteriorly. Dorsal valve weakly and regularly convex with an incurved umbo. Fold narrow, with one pair of anteriorly fasciculate costae. The costae pattern on the flanks is similar to that of the ventral valve. Concentric growth lamellae poorly preserved.

Interior: Low apical callus at the apex of delthyrium. Dental plates short (2-3 mm), sub-parallel to weakly divergent. Muscle field distinct, rhomboidal and oval in outline, bisected by a variably developed median ridge. Anterior part of the muscle area strongly elevated. Muscle scars arranged longitudinally. Genital marks radially arranged as pits on each side of the muscle field. Dorsal valve with a weak median myophragm extends anteriorly of the cardinal process. Ventral and dorsal interiors weakly reflect the external costae. Other features unknown.

\section{Discussion}

The material described herein is certainly conspecific with the one assigned to Punctothyris riojanensis by Lech and Aceñolaza (1987, p. 259, pl. 2, figs. 8-9), from the same horizons of the Río del Peñón Formation. However, the generic attribution by those authors was incorrect. The type species of the genus Punctothyris (Punctothyris argus Hyde, 1953), from the Carboniferous of North America, shows a "punctate shell" that, according to some authors (Boucot et al., in Moore ed., 1965) should be interpreted as bases of spines. This spinose ornament is absent in Lech and Aceñolaza's material, and is considered a diagnostic character for the family Gerkispiridae in which the genus Punctothyris is included (Carter et al., 1994).

The array of diagnostic characteristics observed in the material described (e.g. external shell morphology, absence of cardinal plates, presence of cardinal callus and dental plates), suggests its inclusion in Trigonotreta. However, Trigonotreta riojanensis shows some differences from the type species such as the absence of 

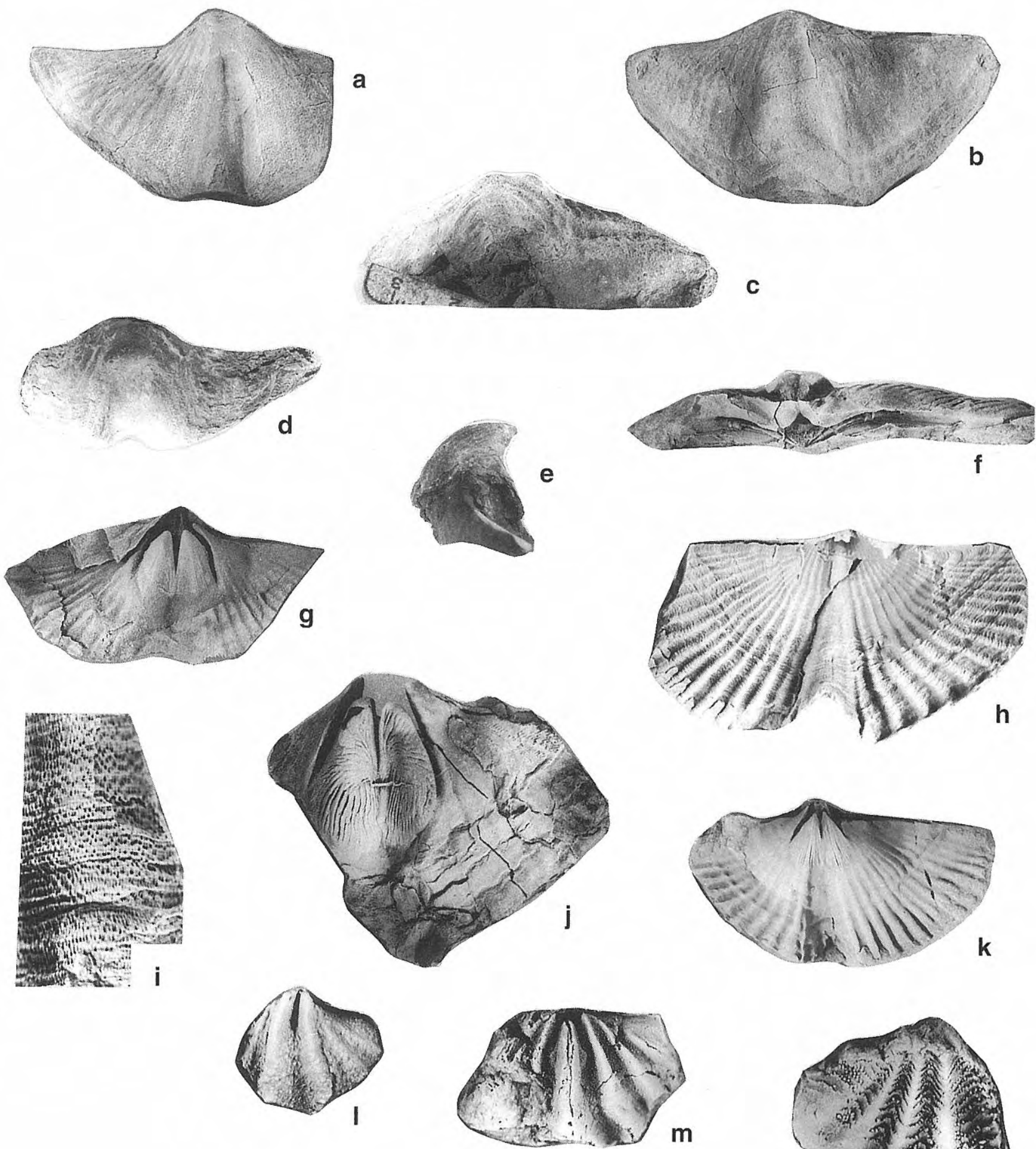

m

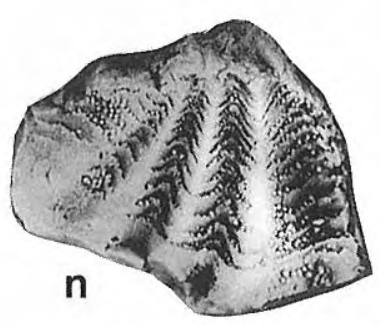

Figure 7. a-k. Septosyringothyris jaguelensis Lech. a, d. ventral valve, ventral and anterior views, IPI 3066, x1. b, c. dorsal valve, dorsal and anterior views, IPI 3067, x1. e, incomplete ventral valve, lateral view, IPI 3009, x2. f, internal mould of dorsal valve, posterior view, IPI 3021, x1. g, internal mould of ventral valve, IPI 3049, x1. h, k, external and internal moulds of ventral valve, IPI $3001 \mathrm{~b}$ (x1.5), 3001a (x1). i, detail of the micro-ornament of fragmentary external mould of ventral valve, IPI 3026, x4. j, ventral valve internal mould of mature specimen, IPI 3053a, x1. l-n. Spiriferellina sp. 1, internal mould of incomplete articulate specimen, ventral view, IPI 3183 A', x5. m-n, internal and external mould of dorsal valve, IPI 3183B-B', x3.5.

the typical fasciculation of the lateral costae into groups of three, and less developed apical callus. Nevertheless, these differences do not justify, in our opinion, a different generic placement. Carter (1990) also suggested that the costae pattern of the Trigonotreta species could be highly variable. 
In relation with Australian species, T. riojanensis is morphologically close to juvenile and submature specimens of T. victoriae Archbold, described from the Asselian-early Tastubian of eastern Australia (Archbold, 1991, p. 323, figs. 2A-X). However, large adult specimens of $T$. victoriae have rounded cardinal extremities and a typical costae pattern in fascicles of three costae.

The Himalayan species $T$. orientensis Singh and Archbold (1993, p. 70, fig. 10A-J) differs from our species in the number and nature of the costae pattern. However, both species show the transverse character of adult individuals. T. hesdoensis (Sanhi and Dutt), a species recorded from peninsular India (Sahni and Dutt, 1959; Archbold et al., 1996), resembles the Argentine species in its weakly fasciculate costae pattern.

Material from the Del Salto Formation referred by Lech and Aceñolaza (1990, p. 84-85, pl. 1, A, photographs 1-3) to Punctothyris sanjuanensis is very close to our $T$. riojanensis specimens. These authors point out three diagnostic features to differentiate $P$. sanjuanensis, i.e. angular cardinal extremities, maximum width coincident with the cardinal line and the absence of a small septum in the ventral valve. Of these characters, the first two were also observed in the material from Río del Peñón. It should be noted that in the genus Trigonotreta, individuals within a single species vary from rounded to transverse according to the ontogenetic stage of the specimens. As to the third diagnostic feature mentioned by Lech and Aceñolaza, these authors themselves state that the presence of an apical callus could be masking the median septum. However, we would need a better review of the Del Salto material to confirm a conspecific condition with our material from Río del Peñón.

\section{Trigonotreta sp. Fig. 6 j-r}

Locality: Eastern limb of the Rincón Blanco syncline, 35 $\mathrm{km}$ west of Jaguié, La Rioja province.

Stratigraphical horizon: Río del Peñón Formation, lower member, horizons 5' and 6'.

Material: Six internal moulds of ventral valves (IPI 3115, $3116,3118,3120,3123,3125 \mathrm{~B}$ ); two incomplete internal moulds of dorsal valves (IPI 3122, 3124); four internal moulds of articulate specimens (IPI 3117, 3119, 3121, 3125C); one external mould of ventral valve (IPI 3125B'); one external mould of dorsal valve (IPI 3125A'). Additional fragmentary material (IPI 3125E). All this material proceed from the horizon 6'.

\section{Description}

Exterior: Small to medium-sized shell with angular cardinal extremities; maximum width immediately anterior to hinge line. Ventral valve more convex than the dorsal one; umbo incurved; sulcus narrow, starting at the umbo and widening towards the anterior commisure. Dorsal valve with a narrow fold, better differentiated from the flanks at the anterior margin.

The bifurcate costae pattern is poorly preserved. In the juvenile specimens the flanks show 7 costae (measured on the posterior region of the valves). Adult specimens exhibit fasciculate costae at mid-length of shell, where they number about 10 costae on each flank. Fold costate, with two fasciculate costae. Costae in the sulcus are not preserved. Concentric growth lamellae poorly preserved.

Interior: Apical callus at the apex of delthyrium. Muscle field distinct, sub-rhomboidal to oval, postero-laterally bounded by short and divergent dental plates. Strong muscle scars impressed longitudinally throughout the field. Genital marks radially arranged as pits on each side of the muscle field. Dorsal valve with a delicate median myophragm. Other characters unknown. Ventral and dorsal interior weakly reflecting the external costae pattern.

\section{Discussion}

Although very fragmentary, this material shows enough diagnostic characteristics to place it in Trigonotreta. Because the preservation of these specimens is so poor, it is difficult to compare with Trigonotreta riojanensis, described from the middle member of the Río del Peñón Formation. However, in Trigonotreta sp. the maximum width occurs slightly anterior to the hinge line. Both species are very similar internally, but in $T$. riojanensis the dental plates are slightly longer and less divergent and the muscle area is more elevated. The costae appear finer than in the species discussed above.

Specimens here studied are inadequate for precise comparison with other described Trigonotreta species. Nevertheless, Trigonotreta sp. shows a weakly fasciculate costae pattern characteristic of the oldest Indian species, such as Trigonotreta hesdoensis (Sanhi and Dutt) from the Asselian-Tastubian faunas of peninsular India (Archbold et al., 1996).

Order SPIRIFERINIDA Ivanova, 1972

Suborder SPIRIFERINIDINA Ivanova, 1972

Superfamily SYRINGOTHYRIDOIDEA Fredericks, 1926

Family Syringothyrididae Fredericks, 1926

Subfamily Septosyringothyridinae Massa, Termier and Termier, 1974

Genus Septosyringothyris Vandercammen, 1955

Type species: Septosyringothyris demaneti Vandercammen, 1955. Lower Carboniferous of Belgium.

\section{Remarks}

Vandercammen (1955) proposed the genus Septosyringothyris for punctate syringothyrid species sharing the following characters: smooth sulcus and fold, transverse delthyrial plate with a syrinx connected to the ventral valve floor by a conspicuous median septum. 
These features allow to separate it easily from Syringothyris Winchell.

In the latest revision of the spiriferids (Carter et al., 1994) the Septosyringothyridinae includes only Septosyringothyris and Histosyrinx Massa et al., 1974. Histosyrinx lacks a transverse delthyrial plate; instead it has two partly joined plates (equivalent to the stegidial sheets), where the syrinx is directly inserted at the junction of these plates.

Septosyringothyris has been recorded from the lower Carboniferous of Belgium (Vandercammen, 1955), and the upper Carboniferous of the Pamirs, Russia (Volgin, 1965). Recently, Isaacson and Dutro (1999) described from the lower Carboniferous of the Northern Chile, the oldest occurence of the genus in western South America.

In Argentina, Septosyringothyris was first described from the Carboniferous of the Precordillera (in Keidel and Harrington, 1938) with the species S. keideli (Harrington). Afterwards, many authors have mentioned it for rocks from Patagonia and the Precordillera, being an ubiquitous element of the Carboniferous-Permian of this region.

\section{Septosyringothyris jaguelensis Lech, 1986} Fig. 7 a-k

*1986 Septosyringothyris jaguelensis Lech, 57-60, pl. 1, fig. 1-5.

1987 Septosyringothyris jaguelensis Lech; Lech and Aceñolaza, 259, pl. 3, fig. 7; pl. 3, fig. A.

Locality: Western limb of the Rincón Blanco syncline, 35 $\mathrm{km}$ west of Jagüé, La Rioja province.

Stratigraphical horizon: Río del Peñón Formation, middle member, horizons 7, 10 and 11 .

Material: Fifteen internal moulds of ventral valves (horizon 10: IPI 3078, 3083, 3086a, 3091; horizon 11: IPI 3001a, 3002, 3019, 3022a, 3023, 3034, 3037a, 3049, 3050, 3051, 3053a); eight external moulds of ventral valves (horizon 7: IPI 3064b; horizon 10: IPI 3076b, 3081b, 3086b; horizon 11: IPI 3001b, 3022b, 3037b, 3053b); fifteen internal moulds of dorsal valves (horizon 10: IPI 3085, 3089; horizon 11: IPI 3004, 3005a, 3007, 3008, 3017, 3018, 3021, 3024, 3025, 3036a, 3047a, 3048, 3052a); four external mould of dorsal valves (horizon 7: 3074b; horizon 11: IPI 3005b, 3036b, $3052 \mathrm{~b}$ ); ten ventral valves (horizon 7: IPI 3064a, 3066, 3071, 3072; horizon 10: 3076a, 3081a, 3082, 3090, 3092; horizon 11: IPI 3009); twelve dorsal valves (horizon 7: IPI 3063, 3065, 3067, 3068, 3069, 3070, 3073, 3074; horizon 10: IPI 3079, 3080, 3084, 3087); two internal mould of articulate specimens and its external moulds (horizon 11, IPI 3006a-b and 3020a-b); one hundred incomplete internal and external moulds and valve fragments (IPI 3026, 3075, 3093).

\section{Description}

Exterior: Shell punctate, large, transverse (length/maximum width 0.5 to 0.7 ), with angular cardinal extremities. Ventral valve gently convex, umbo weakly inflated, moderately to strongly incurved over a high and weakly concave interarea. Umbonal angle $95^{\circ}$ to $110^{\circ}$ and delthyrial angle of $45^{\circ}$ to $65^{\circ}$. Sulcus broad and distinct, widening anteriorly about 0.25 to 0.20 of the maximum width. Dorsal valve with a weakly prominent umbo; fold clearly distinct from the flanks, with a rectangular section and a weak median sulcus. Costae pattern is similar on each valve. Ontogeny reflects three changes in the costae number, ranging from juvenile stages with $8-12$ costae, juvenilesubmature stage with $12-18$ and matures stages with 16-18 costae on each flank. Micro-ornament of fine radial striae with fine elongate pustules between striae producing textilelike appearance. Concentric growth lines very conspicuous, c. 2-3 per mm near mid-length of shell.

Interior: Dental plates strong, reaching up to 0.35 to 0.33 of valve length; dental plates divergent $50^{\circ}$ to $65^{\circ}$. Delthyrial plate poorly developed (3.5 to $4 \mathrm{~mm}$ ), connecting the posterior ends of dental plates. Distinct median septum connecting the syrinx with the valve surface. In juveniles, the median septum is a delicate ridge, becoming very conspicuous only in mature specimens. Muscle field better defined in mature specimens. Two sorts of ventral diductor scars lie between and in front of the dental plates: longitudinal scars occupying the anterior part of the muscle field and radial scars disposed at the posterior part of it. Dorsal interior with a distinctive large and striated cardinal process and deep, extended dental sockets. Weak median septum rising anteriorly to cardinal process, reaching up to 0.5 of the valve length.

\section{Discussion}

The morphological features observed on our specimens allow us to include them in Septosyringothyris jaguelensis Lech, described from the Agua de Jagüel (Lech, 1986, p. 57, pl. 1, figs. 1-5) and Río del Peñón (Lech and Aceñolaza, 1987, p. 259, pl. 2, fig. 7) formations. Some differences (umbonal curvature, number of costae in mature specimens and umbonal angle) with the type material, does not warrant specific differentiation.

Also, Lech and Aceñolaza (1987, p. 257-259, pl. 2, fig. 4-6; pl. 3, fig. C) described S. jaguensis from the Río del Peñón Formation and stated as distinctive characteristics in relation to $S$. jaguelensis, the number of costae per flank (15 vs. 18) and the shell length/width ratio. The specimens referred by us to $S$. jaguelensis show a considerable range of variation in these characteristics according to the ontogenetic stage (costae per flank: 10 to 18 ; L/W ratio: 0.5 to 0.7 ). However, they could not be compared more closely with $S$. jaguensis since this species was based on very fragmentary material and its original description is too vague. For this reason, we can't decide whether S. jaguensis and S. jaguelensis are conspecific.

S. jaguelensis shows significant differences (internal and external) with the Carboniferous species S. keideli (Harrington) from the Leoncito and La Capilla Formations (Keidel and Harrington, 1938; Amos et al., 1963; Cisterna, 1997). S. jaguelensis, herein described, 
lacks the pyramidal shape of the ventral valve of $S$. keideli, the umbo is generally stronger incurved and the sulcus is narrower and deeper. The dorsal valve shows a high fold of sub-rectangular section, generally provided of a median sulcus. Internally, the dental plates and the median septum are longer and thicker than in S. keideli.

S. amosi Lech and Aceñolaza, 1990 (p. 85-86, pl. 1,A, photographs 4-7) and S. globosa Lech, 1993 (p. 564-566, pl. 1, fig. 4-5), described from the Del Salto Formation, have inflated shells that can be very large at maturity, with rounded cardinal extremities and a smaller variation of the delthyrial angle.

In relation to the South American species $S$. covacevichi Isaacson and Dutro, 1999 (p. 629, figs. 3.13.8), S. jaguelensis has a smaller umbonal angle and the ventral interior shows more conspicuous dental plates and median septum.

The type species of Septosyringothyris, S. demaneti, described from the Carboniferous of Belgium (Vandercammen, 1955, p. 2; pl. 1, fogs. 1-8) is smaller, with a narrower sulcus and a smooth fold. It also usually shows a bifid ventral median septum.

S. tomiensis Sokolskaya (Sarytcheva et al., 1963, p. 279, pl. 49, figs. 11-19), can be separated from $S$. jaguelensis by its smaller size and more numerous lateral costae (19-20). Also, the Russian species S. pamirensis Volgin, 1965 (p. 146, figs. a-g), can be differentiated from $S$. jaguelensis fundamentally because its outline is more transverse and the fold smooth and weaker than in the Argentine species.

Superfamily PENNOSPIRIFERINOIDEA Dagis, 1972 Family Crenispiriferidae Cooper and Grant, 1976 Genus Spiriferellina Fredericks, 1924

Type species: Terebratulites cristatus Schlotheim, 1816. Late Permian, Pössneck, Thuringia (Germany).

\section{Spiriferellina sp.} Fig. 7 1-n

Locality: Eastern limb of the Rincón Blanco syncline, 35 km west of Jagüé, La Rioja province.

Stratigraphical horizon: Río del Peñón Formation, lower member, horizons 5' and 6'.

Material: One incomplete internal mould of an articulated specimen with its external mould of the ventral valve (IPI $3183 \mathrm{~A}^{\prime}-\mathrm{A}$ ); two internal moulds of ventral valves (IPI 3183D, 3183E); two internal moulds of dorsal valves (IPI 3183B, 3183C); one external mould of dorsal valve (IPI 3183 B'). All material from the horizon 6'.

\section{Description}

Small punctate shell with angular cardinal extremities; maximum width near hinge line; sulcus and fold strong, smooth, about one third of the maximum width, slightly wider than lateral costae. Lateral slopes with 2 to 3 strong and subangular costae. Surface pustulose; conspicuous concentric lamellae (about 2 per $\mathrm{mm}$ at anterior part of the valve). Ventral interior with short dental plates and conspicuous median septum. Dorsal interior with a delicate median myophragm. Other features unknown.

\section{Discussion}

Although incomplete, this material is figured for completeness of the brachiopod faunas from the Río del Peñón Formation and is tentatively referred to Spiriferellina Fredericks.

Spiriferellina sp. is distinguished by its small size for the genus and small number of lateral costae. Even though inadequate for detailed specific comparisons, Spiriferellina sp. is remarkably smaller in relation to Spiriferellina octoplicata (Sowerby) from the Carboniferous of Argentina (Keidel and Harrington, 1938; Amos, 1958, 1979; Amos et al., 1963). Also, Spiriferellina octoplicata generally shows four lateral costae on each flank and slightly smaller number of concentric lamellae per mm.

\section{ACKNOWLEDGEMENTS}

The authors wishes to thank to Dr Neil Archbold (Deakin University of Australia) for critical reading the manuscript and for allowing us the comparison with Australian material. Also, to Dr Guang Shi (Deakin University) for his valuable comments on the first version of this paper.

To reviewers, Drs Jenaro García Alcalde (Universidad de Oviedo) and Cor Winkler Prins (Nationaal Natuurhistorisch Museum, Leiden) for their careful review and advises. To Dr María Luisa Martínez Chacón for her editorial corrections.

The authors are also indebted to Dr Mauricio Martínez (PROGEBA, Bariloche, Argentina), for assistance in the field. CONICET provided the financial support for the field work.

\section{REFERENCES}

Abramov, B. S. and Griegorieva, A. D. 1983. Biostratigraphy and Brachiopoda from the Middle and Upper Carboniferous of Verchoyan. Akademiia Nauk SSSR, Paleontologicheskii Institut, Trudy, 200, 1-168 (in Russian).

Amos, A.J. 1958. Algunos Spiriferacea y Terebratulacea (Brachiopoda) del Carbonífero superior del "Sistema de Tepuel" (provincia de Chubut). Contribuciones Científicas, Facultad de Ciencias Exactas y Naturales, Serie Geología, 2 (3), 95-108.

Amos, A.J. 1961. Algunos Chonetacea y Productacea del Carbonífero inferior y superior del sistema de Tepuel, Provincia del Chubut. Revista de la Asociación geológica Argentina, 15 (1-2), 81-107.

Amos, A.J. 1979. Guía Paleontológica Argentina. Parte I: Paleozoico, faunas carboníferas y pérmicas. Publicación del CONICET, 1-154. 
Amos, A.J., Baldis, B. y Csaky, A. 1963. La fauna del Carbonífero medio de la Formación La Capilla y sus relaciones geológicas. Ameghiniana, 3, 123-132.

Angiolini, L., Bucher, H., Pillevuit, A., Platel, J.P., Roger, J., Broutin, J., Baud, A., Marcoux, J. and Al Hashmi, H. 1997. Early Permian (Sakmarian) brachiopods from Southeastern Oman. Geobios, 30, 379-405.

Antelo, B. 1972. Los braquiópodos del Carbonífero Superior de la Quebrada Larga, en las cabeceras del Río Blanco, provincia de San Juan. Ameghiniana, 9, 159-172.

Archangelsky, S. and Azcuy, C. L. 1985. Carboniferous paleobotany and palynology in Argentina. Compte Rendu du X Congrès de Stratigraphie et de Géologie du Carbonifère. (Madrid, 1983), 4, 267-280.

Archangelsky, S. and Cúneo, N. R. 1991. The Neopaleozoic floristic succession from Northwestern Argentina. A new perspective. In: Gondwana Seven, Proceeding (Eds. H. Ulbrich and A.C. Rocha Campos). Instituto de Geociencias, Sao Paulo, 469-481.

Archangelsky, A. y Lech, R. R. 1985. Presencia de Cancrinella cf. farleyensis Eth. y Dunn (Brachiopoda) en las capas plegadas de la serie Tramojo, en el Pérmico inferior de la Precordillera de Mendoza. I Jornadas de Geología de la Precordillera, 13.

Archangelsky, S., Azcuy, C., Césari, S., González, C., Hünicken, M., Mazzoni, A. y Sabattini, N. 1996. Correlación y edad de las biozonas. In: El Sistema Pérmico en la República Argentina y en la República oriental del Uruguay (Ed. S. Archangelsky). Academia Nacional de Ciencias de Córdoba, 203-226.

Archbold, N.W. 1981. Studies on Western Australian Permian brachiopods. 2. The family Rugosochonetidae Muir-Wood 1962. Proceedings of the Royal Society of Victoria, 93,109-128.

Archbold, N.W. 1983. Permian marine invertebrate provinces of the Gondwanan Realm. Alcheringa, 7, 5973.

Archbold, N.W. 1986. Tivertonia yarrolensis (Maxwell) (Chonetidina, Brachiopoda) from the Permian of the Sydney Basin, Australia. Alcheringa, 10, 413-415.

Archbold, N.W. 1991. Studies on Western Australian Permian brachiopods 10. Faunas from the Wooramel Group, Carnarvon Basin. Proceedings of the Royal Society of Victoria, 103 (2), 55-66.

Archbold, N.W., 1993. Studies on Western Australian Permian Brachiopods 11. New genera, species and records. Proceedings of the Royal Society of Victoria, 105 (1), 1-29.

Archbold, N. W. 1995. Studies on Western Australian Permian brachiopods. 12. Additions to the late AsselianTastubian faunas. Proceedings of the Royal Society of Victoria, 107 (2), 95-112.

Archbold, N. W. 1999. Additional records of Permian brachiopods from near Rat Buri, Thailand. Proceedings of the Royal Society of Victoria, 111 (1), 71-86.

Archbold, N.W. and Gaetani, M. 1993. Early Permian Brachiopoda and Mollusca from the northwest Himalaya, India. Rivista Italiana di Paleontologia e Stratigrafia, 99 (1), 27-56.

Archbold, N.W. and Thomas, G.A. 1984. Neospirifer
Fredericks, 1924 (Spiriferida, Brachiopoda): A review. Journal of Paleontology, 58, 626-635.

Archbold, N.W. and Thomas, G.A. 1986. Neospirifer and Trigonotreta (Spiriferida, Brachiopoda) from the Permian of Western Australia. Alcheringa, 10, 125-161.

Archbold, N.W., Shah, S.C. and Dickins, J.M. 1996. Early Permian Brachiopod faunas from Peninsular India: Their Gondwanan Relationships. Historical Biology, 11, 125 135.

Borrello, A. 1955. Los conglomerados del Cerro Punta Negra, al oeste de Jagüé. Revista de la Asociación Geológica Argentina, 10 (1), 46-53.

Boucout, A. J., Johnson, J.G., Pitrat, C. W. and Stanton, R.D. 1965. Spiriferida. In: Treatise on Invertebrate Paleontology, Part. H, Brachiopoda, v. 2. (Ed. R.C. Moore). University of Kansas Press and Geological Society of America, 523-927.

Briggs, D.J. 1998. Permian Productina and Strophalosiidina from the Sydney-Bowen Basin and New England Orogen: Systematics and biostratigraphic significance. Memoir of the Association of the Australasian Palaeontologists, 19, 1-258.

Carrizo, H. 1998. Estudio de floras eocarboníferas de Argentina y su comparación con las otras regiones relacionadas. Tesis Doctoral. Universidad Nacional de Salta, 1-200 (unpublished).

Carrizo, H. y Azcuy, C. 1995. La Zona NBG (Carbonífero Tardío) en las inmediaciones del Río Agua de Carlos, La Rioja, Argentina. Ameghiniana, 32, 271-278.

Carter, J.L. 1990. New Brachiopods (Brachiopoda: Articulata) from the Late Osagean of the Upper Mississippi Valley. Annals of Carnegie Museum, 59, 219-247.

Carter, J.L., Johnson, J.G., Gourvennec, R. and Hong-Fei, H. 1994. A revised classification of the spiriferid brachiopods. Annals of Carnegie Museum, 63, 327-374.

Cisterna, G. A. 1997. Taxonomía y Paleoecología de los Rhynchonellida, Spiriferida y Strophomenida (Brachiopoda) del Paleozoico tardío de las cuencas Río Blanco y Calingasta-Uspallata, provincias de La Rioja y San Juan. Tesis Doctoral. Facultad de Ciencias Exactas, Físicas y Naturales de la Universidad Nacional de Córdoba, 1-173 (unpublished).

Cisterna, G.A. y Sabattini, N. 1998. Algunos Gastropoda de la Formación Río del Peñón, Carbonífero tardío-Pérmico temprano, provincia de La Rioja, Argentina. Revista de la Asociación Geológica Argentina, 53 (2), 212-218.

Clarke, M.J. 1979. The Tasmanian Permian spiriferid brachiopods Trigonotreta stokesi Koening, 1825, Grantonia hobartensis Brown, 1953 and Spirifer tasmaniensis Morris, 1845. Journal of Paleontology, 53, 197-207.

Cooper, G A. and Grant, R.E. 1975. Permian Brachiopods of West Texas III. Smithsonian Contributions to Paleobiology, 19 (1-2), 795-1921.

Dunbar, C.O. 1955. Permian brachiopod fauna of central east Greenland. Meddedelser om Gronland, 110 (3), 1169.

Erlanger, O.A. 1981. K revizii roda Rhynchopora. Paleontologicheskii Zhurnal, 1981 (1), 88-84. 
Fauque, L., Limarino, O., Cingolani, C. y Varela, R. 1999. Los movimientos intracarboníferos en la Precordillera riojana. XIV Congreso Geológico Argentino, 1, 421-424.

Fredericks, G.N. 1924. On Upper Carboniferous spiriferids from the Urals. Izvestiia Geologicheskogo Komiteta (1919), 38(2), 295-324 (in Russian).

González, C.R. 1993. Late Paleozoic Faunal Succession in Argentina. Comptes Rendus XII ICC-P, Buenos Aires, 1991, 1, 537-550.

González, C.R. y Bossi, G.E. 1986. Los depósitos carbónicos al oeste de Jagüé, La Rioja. IV Congreso Argentino de Paleontología y Bioestratigrafía, 1, 231236.

Grant, R. E. 1976. Permian Brachiopods from Southern Thailand. Paleontological Society, Memoir, 9, 269 pp., 71 pls. (Journal of Paleontology, 50 (3), part. 2).

Harrington, H. J. 1955. The Permian Eurydesma fauna of eastern Argentina. Journal of Paleontology, 29, 112-128.

Hyde, J. E. 1953. Mississipian formations of central and southern Ohio. Bulletin of the Geological Survey of Ohio, 51, 1-355.

Isaacson, P. E. and Dutro, T. 1999. Lower Carboniferous brachiopods from Sierra de Almeida, Northern Chile. Journal of Paleontology, 73, 625-633.

Keidel, J. and Harrington, H. J. 1938. On the discovery of Lower Carboniferous tillites in the Precordillera of San Juan. Geological Magazine, 75, 103-129.

King, R.E. 1865. Remarks on the histology of two specimens of Rhynchopora geinitziana de Verneuil, from near the River Oukhla, Province of Archangel. Annals and Magazine of Natural History, 3 (16), 124-128.

King, R.H. 1938. New Chonetidae and Productidae from Pennsylvanian and Permian strata of north-central Texas. Journal of Paleontology, 12, 257-279.

Koening, C. 1825. Icones Fossilium Sectiles. London, 1-4.

Kozlowski, R. 1914. Les brachiopodes du Carbonifère supérieur de Bolivie. Annales de Paléontologie (Paris), 9, 3-97.

Kutorga, S.S. 1844. Zweiter Beitrag zur Paläontologie Russlands. Verhandlungen der Russisch-Kaiserlichen Mineralogischen Gesellschaft zu St. Petersburg, 4, 62104.

Leanza, F. 1945. Braquiópodos carboníferos de la Qda. de la Herradura al NE de Jáchal. Notas del Museo de La Plata, Sección Paleontología, 10 (18), 277-314.

Leanza, F. 1948. Braquiópodos y Pelecípodos carboníferos de la provincia de La Rioja (Argentina). Revista del Museo de La Plata, Sección Paleontología, 3 (18), 237264.

Lech, R.R. 1986. Septosyringothyris jaguelensis sp. nov. (Brachiopoda) del Pérmico inferior de Mendoza, Argentina. Ameghiniana, 23, 57-60.

Lech, R.R. 1990. Distribución de la fauna de braquiópodos de la Formación Agua de Jagüel (Carbonífero superiorPérmico inferior), provincia de Mendoza, Argentina. XI Congreso Geológico Argentino, 1, 15-18.

Lech, R.R. 1993. El Género Septosyringothyris Vandercammen, 1955, (Brachiopoda) en el CarboníferoPérmico del centro-oeste de Argentina. Comptes Rendus XII ICC-P, Buenos Aires, 1991, 1, 563-571.
Lech, R.R. y Aceñolaza, G. 1987. Braquiópodos en el Peñoniano (Carbonífero superior) de la provincia de La Rioja. IV Congreso Latinoamericano de Paleontología, 1, 255-266.

Lech, R R. y Aceñolaza, G. 1990. Braquiópodos en el Peñoniano de la Formación Del Salto (Carbonífero superior-Pérmico inferior), Provincia de San Juan, Argentina. V Congreso Argentino de Paleontología y Bioestratigrafía, 1, 83-88.

Likharev, B.K. 1938. On some peculiarities in the interior of Productus Sowerby (s.1.). Publications of the laboratory of Paleontology, Moscow University, 4, 287-291.

Massa, D., Termier, G. et Termier, H. 1974. Le Carbonifère de Libye occidentale. Stratigraphie, Paléntologie. Notes et Mémoires Compagnie Française des Pétroles, 11, 139-206.

Moore, R. C. (Ed.) 1965. Treatise on invertebrate Paleontology, Part H, Brachiopoda. Geological Society of America and University of Kansas Press, 1-927.

Muir-Wood, H.M. 1962. On the morphology and classification of the brachiopod suborder Chonetoidea. British Museum (Natural History), London, 132 pp., 16 pls.

Newell, N., Chronic, J. and Roberts, T. 1953. Upper Paleozoic of Perú. The Geological Society of America Memoir, 58, 1-276.

Pujanas, I. 1989. Hallazgo de invertebrados marinos Neopaleozoicos en Tres Lagunas (Depto Río Senguer) Provincia del Chubut y sus implicancias paleogeográficas. IV Congreso Argentino de Paleontología y Bioestratigrafía, 11-28.

Sabattini, N., Ottone, E.G. y Azcuy, C.L. 1990. La Zona de Lissochonetes jachalensis-Streptorhynchus inaequiornatus (Carbonífero tardío) en la localidad de La Delfina, provincia de San Juan. Ameghiniana, 27, 75-81.

Sanhi, M. R. and Dutt, D. K. 1959. Argentine and Australian affinities in a Lower Permian fauna from Manendragarh, central India. Records of the Geological Survey of India, 87, 655-670.

Sarytcheva, T. G. (Ed.) 1968. Late Paleozoic brachiopods from eastern Kazakhstan. Akademiia Nauk SSSR, Paleontologicheskii Institut, Trudy, 121, 1-212 (in Russian).

Sarytcheva, T.G., Sokolskaya, A.N., Besnossova, H.A. and Maximova, S. 1963. Brachiopodi i Paleogeographia Karbone Kouznetzkoi Kotloviny. Akademiia Nauk SSSR, Paleontologicheskii Institut, 95, 1-547.

Schlotheim, E. F. von 1816. Beiträge zur Naturgeschichte der Versteinerungen in geognostischer Hinsicht. Denkschrift Akademie Wissenschaften Munchen, Math.Phys. Kl., 6, 13-36.

Sessarego, H. y Lech, R.R. 1985. Estratigrafía y contenido paleontológico de la Formación Del Salto (Pérmico) aflorante al norte del río San Juan, Cerro El Brealito, Dpto. Calingasta, San Juan. I Jornadas sobre Geología de Precordillera, 27.

Shi, G.R. and Shen, S. 1997. A Late Permian brachiopod fauna from Selong, Southern Xizang (Tibet), China. Proceedings of the Royal Society of Victoria, 109, 37-56.

Shi, G.R. and Waterhouse, J.B. 1991. Early Permian brachiopods from Perak, west Malaysia. Journal of Southeast Asia Earth Sciences, 6 (1), 25-39. 
Shi, G.R. and Waterhouse, J.B. 1996. Lower Permian Brachiopods and Molluscs from the Upper Jungle Creek Formation, Northern Yukon Territory, Canada. Bulletin of Geological Survey of Canada, 424, 1-177.

Shi, G.R., Archbold, N.W. and Fang, Z.-J. 1995. The biostratigraphical and palaeobiogeographical significance of an Early Permian brachiopod fauna from the Dingjiazhai Formation, Baoshan Block, Western Yunnan, China. Geological Survey of Vietnam, Journal of Geology, Series B, 5-6, 63-74.

Shi, G.R., Fang, Z.-J. and Archbold, N.W. 1996. An Early Permian brachiopod fauna of Gondwanan affinity from the Baoshan Block, Western Yunnan, China. Alcheringa, 20, 81-101.

Simanauskas, T. 1991. Lissochonetes jachalensis Amos, 1961. (Brachiopoda, Chonetacea). Redescripción morfológica y ontogenia. Ameghiniana, 28, 135-143.

Simanauskas, T. 1993. Las Superfamilias Chonetacea y Productacea, (Brachiopoda) del Paleozoico superior de la cuenca Tepuel-Genoa, Chubut. Tesis doctoral inédita. Facultad de Ciencias Naturales y Museo, UNLP, 1-114.

Simanauskas, T. 1996. Un supuesto Chonetoidea del Pérmico de Patagonia reasignado a un género de Productoidea (Brachiopoda) Ameghiniana, 33, 349-351.

Simanauskas, T. and Cisterna, G. 2000. A palaeoopportunistic brachiopod from the Early Permian of Argentina. Alcheringa, 24, 45-53.

Singh, T. and Archbold, N.W. 1993. Brachiopoda from the Early Permian of the Eastern Himalaya. Alcheringa, 17, 55-75.

Taboada, A.C. 1998. Dos nuevas especies de Linoproductidae (Brachiopoda) y algunas consideraciones sobre el Neopaleozoico sedimentario de las cercanías de Uspallata, Argentina. Acta Geológica Lilloana, 18 (1), 69-80.
Taboada, A.C. 1999. The interval between the Levipustula and Costatumulus biozones in Patagonia. Newsletter on Carboniferous Stratigraphy, 17, 11.

Thomas, G.A. 1958. The Permian Orthotetacea of Western Australia. Bulletin Bureau of Mineral Resources, Geology and Geophysics, Australia, 39, 1-115.

Thomas, G.A. 1971. Carboniferous and Early Permian Brachiopods from western and northern Australia. Bulletin Bureau of Mineral Resources, Geology and Geophysics, Australia, 56, 157-168.

Vandercammen, A. 1955. Septosyringothyris demaneti nov. sp. et nov. gen., un syringothyride nouveau du Dinantien de la Belgique. Bulletin de l'Institut Royal des Sciences Naturelles de Belgique, 31 (30), 1-5.

Verneuil, E. 1845. Paléontologie Mollusques, Brachiopodes. In: Géologie de la Russsie d'Europe et des Montagnes de l'Oural (Eds. R.I. Murchisson, E. de Verneuil and A. de Keyserling), 2 (3), 17-395.

Volgin, G.I. 1965. Occurrence of genus Septosyringothyris in the Upper Carboniferous of the East Pamirs. Paleontologicheskii Zhurnal, 1965, 145-147 (in Russian), Translated in International Geology Review, 8 (7), 848-850.

Waterhouse, J.B. 1982. An Early Permian cool-water fauna from pebbly mudstones in south Thailand. Geological Magazine, 119, 337-354.

Waterhouse, J.B. and Gupta, V. J. 1978. Early Permian fossils from the Bijni tectonic unit, Garhwal Himalayas. Recent Researches in Geology, 4, 410-437.

Waterhouse, J.B., Briggs, D.J.C. and Parfrey, S.M. 1983. Major Faunal Assemblages in the Early Permian Tiverton Formation near Homevale Homestead, Northern Bowen Basin, Queensland. In: Permian Geology of Queensland, Geological Society of Australia, Brisbane, 121-138. 